Jakub Bajer, Andrea Mariani

(Poznań)

\title{
MACOCHA IDEALNA: AKTYWNOŚĆ ANNY LUIZY Z MYCIELSKICH RADZIWIŁŁOWEJ W ŚWIETLE FRANCUSKIEJ KORESPONDENCJI DYPLOMATYCZNEJ (1764-1765)
}

DOI 10.14746/SEG.2014.10.13

\begin{abstract}
This article offers an insight into the diplomatic activities of princess Anna Luiza Radziwiłłowa née Mycielska, second wife and widow of the grand hetman of Lithuania, Michał Kazimierz "Rybeńko" Radziwiłł, in the aftermath of the election of Stanisław August to the Polish throne. The main source of information is the diplomatic correspondence between France and Gdańsk. The princess lived there while her stepson was in exile as a result of his opposition to the new king. The purpose of the article is to show how Anna Luiza tried to gain political support from France and how her efforts were perceived by the French diplomacy.

\section{Key words}

Anna Luiza Radziwiłłowa née Mycielska, Karol Stanisław "Panie Kochanku" Radziwiłł French diplomacy, king Stanisław August, the Czartoryski family, $18^{\text {th }}$ century, Gdańsk, Dantzig, Polish-Lithuanian Commonwealth
\end{abstract}


W czerwcu 1787 r. odbyła się w Nieświeżu niezwykła ceremonia. Z inicjatywy właściciela miasta, wojewody wileńskiego Karola Stanisława Radziwiłła „Panie Kochanku”, pochowano w kościele pod wezwaniem Bożego Ciała zwłoki macochy i brata przyrodniego gospodarza - Anny Luizy z Mycielskich Radziwiłłowej i Hieronima Wincentego. Ciało Radziwiłłowej, zmarłej w Dreźnie 19 marca 1771 r., spoczywało tymczasowo w kościele Filipinów w Gostyniu z powodu trudnej sytuacji, która nastała dla rodu Radziwiłłów w okresie konfederacji barskiej. Dopiero po szesnastu latach, wraz ze śmiercią jej syna Hieronima Wincentego, okoliczności pozwoliły zrealizować wolę, którą Anna Luiza wyraziła w testamencie, aby godnie pochowano ją w krypcie Radziwiłłów w kościele farnym nieświeskim ${ }^{1}$. Przy urządzaniu ceremonii pogrzebowej nawiązywano do tradycji wielodniowych uroczystości, które odbywały się w kręgu Radziwiłłów co najmniej od połowy XVII w. Dla obecnych, którzy świeżo pamiętali trudne losy nestora rodu Karola Stanisława „Panie Kochanku” w okresie elekcji Stanisława Augusta i wojny polsko-rosyjskiej wybuchłej po zawiązaniu konfederacji barskiej, wspomniana uroczystość stanowiła ideowy krok ku odbudowie prestiżu familii radziwiłłowskiej.

Z ambony zabrzmiały słowa Józefa Katenbringa, byłego jezuity, związanego z Radziwiłłami od połowy lat 50., a w chwili owego wystąpienia zajmującego stanowisko proboszcza nieświeskiego. Kazanie pogrzebowe rozpoczynało się cytatem biblijnym z „Księgi Tobiasza”, za pomocą którego autor podkreślał nadzwyczajne przywiązanie „Panie Kochanku” do macochy, wręcz jakby była jego matką ${ }^{2}$. Następnie Katenbring zarysował barwny portret Anny Luizy. Przede wszystkim podkreślał jej przezorność w wychowaniu dzieci, porównując ją do matki króla Francji świętego Ludwika³. W dalszym ciągu

${ }^{1}$ Testament został sporządzony 14 III 1771 r. w Dreźnie. Zob. Archiwum Główne Akt Dawnych (dalej AGAD), Warszawskie Archiwum Radziwiłłów (dalej AR), XI, 157, s. 1.

2 „Honorem habebis Matri tuae omnibus diebus vitae eius, cum autem et ipsa compleverit tempus vitae suae, sepelias eam juxta me" - Szanuj swoją matkę i nie zapomnij o niej przez wszystkie dni jej życia. [...] A kiedy umrze, pochowaj ją obok mnie w jednym grobie (Tb 4, 3-4).

${ }^{3}$ „Znała publiczność cała, oczy nasze na to patrzały, jak śliczna młodość wasza pod okiem tak przezornej, tak doskonałej Matki codziennie kształcona została; sama będąc najpiękniejszym wzorem wszelkich cnót chrześcijańskich, pańskich y żeńskich, też same cnoty w miękkie serca wasze wszczepiać y wpajać starała się, prawdziwie jak druga Blanka Ludwika świętego Matka te słowa Ducha S. najczęściej y najżywiej wam powtarzała: „Deum time, mandata eius serva, hoc est enim omnis homo". Cyt. Opisanie dzienne pogrzebów J.O. X. Anny z Micielskich Radziwiłłowy wojewodziny wileńskiej hetmanowy W. W.X.L. y J.O. X. Jmci Hieronima Radziwiłła podkomorzego W. W.X.L. starosty sądowego województwa mińskiego rotmistrza kawaleryi 
argumentacji proboszcz nieświeski wykraczał już zdecydowanie poza konwencję pochwalną, właściwą dla kazania pogrzebowego, w którym zmarłej szlachciance przydzielano tradycyjnie rolę wiernej żony i matki. Katenbring postanowił poruszyć kwestię politycznego znaczenia Anny Luizy w okresie elekcji Stanisława Augusta, wkraczając w ten sposób w obszar aktywności właściwej dla męskich przedstawicieli szlachty. Duchowny wychwalał niezachwianą lojalność Anny Luizy wobec pasierba Karola Stanisława w obliczu prób konfederacji generalnej litewskiej nakłonienia jej do odstąpienia od opozycji wobec nowego władcy. Fragment tekstu, wykorzystujący styl prozopopei, zasługuje na zacytowanie:

„Dopiero kiedy ta burza wiadoma na dom ks. postała, czego ta przedziwna matka nie czyniła: zgromadziwszy pod skrzydła swoje, iż tak rzekę, młode pisklęta domu książęcego, uleciała nam z niemi za granicę ojczystą. Dokąd matko troskliwo! Dokąd się puszczasz, a dom, bogactwa, wygody, panowanie y samą ojczyznę twoją rzucasz? Tam, mówi księżna, gdzie głowa naszej familii, gdzie opiekun moich dzieci, gdzie najukochańszy pasierb mój, tam losy przykre chętnie z nim dzielić będę, a kochane potomstwo moje w zagranicznej zaciszy do wszelkich cnot y przymiotów rodu swego godnych przysposabiać. Ale się tu w kraju zostać możesz, dostatków Radziwiłłowskich bezpiecznie używać, obszernemi dobrami zupełnie władać y rozrządzać, Warszawa Ci to przyrzeka. Mieszkałem na ów czas w Warszawie, znajdowałem się na pokojach w Bogu zeszłej Księżnej, kiedy przez usta ministerialne takie jej doszło oświadczenie: 'Stany zgromadzone mogą powierzyć W. Ks. Mości rząd zupełny wszystkiemi dobrami pod sąd y opiekę dotąd oddanemi, tylko W. Ks. Mość cóż tylko odstąp Księcia Wojewodę. Ach rzecze z płaczem Księżna! Mnie matce odstąpić syna? Mnie wdowie odstąpić opiekuna? Wolę nic nie mieć y z rąk patrzyć Księcia wojewody, niżeli Go sobie w najmniejsze rzeczy narazić. On mię szanuje jako Matkę, ja Go kocham jako syna. Musi się to wszystko odmienić. Tak rzekła, y z Warszawy do Drezna powróciła"4.

Należy tu podkreślić, że kazanie warmińskiego jezuity dokładnie odzwierciedlało wydarzenia historyczne, z wyjątkiem szczegółu powrotu Anny Luizy

narodowey kawalera orderów polskich św. Huberta obchodzonego w Nieświzu 1787 czerwca 20 dnia, Wilno 1787, s. 27.

${ }^{4}$ Ibidem, s. 28-30. 
do Drezna ${ }^{5}$. Narada, o której Katenbring wspomina jako naoczny świadek, odbyła się w Warszawie w lutym 1765 r. Wskazują na to nie tylko źródła zakonne $e^{6}$, ale też korespondencja dyplomatyczna wykorzystywana przez autorów niniejszego artykułu.

W literaturze historycznej postać Anny Luizy pozostawała dotychczas na marginesie uwag. Mimo istnienia w „Polskim Słowniku Biograficznym” jej biogramu autorstwa Hanny Dymnickiej-Wołoszyńskiej oraz licznych wzmianek w herbarzach i opracowaniach monograficznych Anna Luiza pozostawała $\mathrm{w}$ cieniu wybitniejszych dam zamężnych z przedstawicielami rodu radziwiłłowskiego, takich jak Anna Katarzyna z Sanguszków lub Franciszka Urszula z Wiśniowieckich. Podobnie przedstawia się sytuacja w przypadku studiów literaturoznawczych ${ }^{7}$, w których najwyżej wzmiankuje się o zachowanych utworach Anny Luizy ${ }^{8}$. O niezbyt rozwiniętym stanie badań nad życiem Anny Luizy świadczy również wspomniany już biogram z „Polskiego Słownika Biograficznego", który ostatnim latom życia Radziwiłłowej poświęca zaledwie kilka linii9 . O nikłym zainteresowaniu postacią Anny Luizy decydowała wreszcie niewielka ilość wydanych źródeł na temat jej działalności. Należy do nich zaliczyć jedynie pojedyncze listy, jakie zostały opublikowane w zbiorach korespondencji Karola Stanisława „Panie Kochanku” ${ }^{\text {. }}$

${ }^{5}$ Wprawdzie Anna Luiza udała się w 1765 r. do Drezna, ale wcześniej jeszcze powróciła na parę miesięcy do Gdańska.

${ }^{6}$ W katalogu osobowym dla roku szkolnego 1764/1765 Józef Katenbring widniał jako kaznodzieja niedzielny w warszawskiej kolegiacie św. Jana. Zob. Catalogus provinciae Masoviae Societatis Jesu ex Anno 1764 ad Annum 1765, Varsavia [1764], s. 2. Rok później Katenbring znajdował się już w Nieświeżu.

${ }^{7}$ A. Sajkowski, Z dziejów teatru nieświeskiego (1746-1762), Pamiętnik Teatralny 10, 3, 1961, s. 422, 425-430; B. Judkowiak, Franciszka Urszula Radziwiłłowa - w poszukiwaniu własnego głosu. Propozycje interpretacyjne, dokumentacyjne i edytorskie, Poznań 2013, s. 85-88.

${ }^{8}$ Należą do nich wiersze napisane po śmierci pierwszego męża Leona Michała (Biblioteka Jagiellońska, sygnatura 119) i utwór skierowany do biskupa smoleńskiego Jerzego Mikołaja Hylzena (Biblioteka Narodowa, sygnatura 3260). Inne rękopisy znajdują się w Bibliotece Czartoryskich (sygnatury 478 i 684), w Bibliotece Narodowej (sygnatury 3258 i 3263) oraz w Zakładzie Narodowym im. Ossolińskich (sygnatura 13566).

${ }^{9}$ H. Dymnicka-Wołoszyńska, Radziwiłłowa Anna Ludwika (1729-1771), [w:] E. Rostworowski (red.), Polski Słownik Biograficzny (dalej PSB), 30, Wrocław-Warszawa i in. 1987, s. 388.

${ }^{10}$ Korespondencya księcia Karola Stanisława Radziwiłła wojewody wileńskiego „Panie Kochanku” (1744-1790) z archiwum w Werkach, red. C. Jankowski, Warszawa 1898; Korespondencya ks. Karola Stanisława Radziwiłła wojewody wileńskiego „Panie Kochanku” (1762-1790) 
Celem artykułu jest próba wypełnienia, choć częściowo, tej luki badawczej na podstawie analizowanej korespondencji dyplomatycznej z czasu bezkrólewia po śmierci Augusta III oraz pierwszych dwóch lat panowania Stanisława Augusta $^{11}$. Jest ona przechowywana przede wszystkim w zbiorach francuskiego Ministerstwa Spraw Zagranicznych ${ }^{12}$, w Bibliotece Polskiej w Paryżu ${ }^{13}$, w Państwowym Archiwum Głównym Saksonii w Dreźnie ${ }^{14}$, w Archiwum Państwowym w Turynie ${ }^{15}$ oraz w londyńskich Archiwach Narodowych ${ }^{16}$. Wśród badanych materiałów znajdują się nieznane do tej pory listy samej Anny Luizy pisane do króla Francji Ludwika XV, jego ministra księcia de Praslin ${ }^{17}$ oraz do byłego francuskiego ambasadora w Polsce markiza de Paulmy ${ }^{18}$. Pośrednikiem w przekazywaniu tej korespondencji był francuski konsul w Gdańsku Jean-François Dumont ${ }^{19}$, który przez ponad rok miał okazję obserwować i relacjonować poczynania Radziwiłłowej, samemu będąc adresatem wielu jej próśb.

W trakcie przygotowywania niniejszego artykułu korzystano również z obszernej korespondencji Radziwiłłowej, przechowywanej w Archiwum Głównym Akt Dawnych w Warszawie. Dla podejmowanego tu zagadnienia ma

ze zbiorów familijnych, red. K. Waliszewski, Kraków 1888; Listy księcia Karola Stanisława Radziwiłła „Panie Kochanku” (1751-1790) z różnych archiwów, red. E. Łuniński, Warszawa 1906.

${ }^{11} \mathrm{~W}$ cytowanych źródłach dyplomatycznych ortografia została zmodernizowana, natomiast w źródłach pochodzących od samej Anny Luizy zachowano oryginalną pisownię.

${ }^{12}$ Archives du Ministère des Affaires Etrangères (dalej AMAE), seria Correspondance politique (dalej CP), działy Pologne (sygn. 285 i 288), Saxe (sygn. 50, 51 i 52), Autriche (sygn. 299, 300 i 301) oraz przede wszystkim Dantzig na lata 1764-1765 (sygn. 21 i 22).

${ }^{13}$ Polskie Towarzystwo Historyczno-Literackie/Biblioteka Polska w Paryżu (dalej BPP), zbiory: „Archiwum księcia Ksawerego Saskiego” (sygn. 74/7) oraz „Papiery prymasa Władysława Łubieńskiego dotyczące ostatniego bezkrólewia 1763-1764” (sygn. 33/3).

${ }^{14}$ Sächsische Haupstaatsarchiv Dresden (dalej SHSA), dział Geheimes Kabinett 10026 (sygn. 2744/4, 2745/1, 3691/1 i 3583/5).

${ }^{15}$ Archivo di Stato di Torino (dalej AST), seria Corti Straniere (dalej CS), dział Polonia (sygn. 1).

${ }^{16}$ The National Archives (dalej TNA), seria State Papers (dalej SP), dział Poland and Saxony (sygn. 88/93).

${ }^{17}$ César Gabriel, hrabia de Choiseul, książę de Praslin, minister spraw zagranicznych Francji od 1761 do $1766 \mathrm{r}$.

${ }^{18}$ Marc Antoine René de Voyer d’Argenson, markiz de Paulmy, francuski ambasador w Polsce w latach 1760-1764.

${ }^{19}$ Jean-François Dumont był rezydentem francuskim w Gdańsku w latach 1756-1768, o celach jego działalności zob. E. Cieślak, Francuska placówka konsularna w Gdańsku w XVIII wieku. Status prawny — zadania — działalność, Kraków 1999, s. 25-33. 
ona wartość uzupełniającą, gdyż pozwala ustalić trasę podróży Anny Luizy, a także naświetlić kontakty rodzinne, przede wszystkim z Michałem Kazimierzem Radziwiłłem „Rybeńką”, a po jego śmierci z Karolem Stanisławem „Panie Kochanku"20. Ponadto postać Anny Luizy została wielokrotnie wspomniana w diariuszu „Rybeńki” ${ }^{21}$, w „Pamiętnikach” Marcina Matuszewicza ${ }^{22}$ oraz w pojedynczych jednostkach Warszawskiego Archiwum Radziwiłłów ${ }^{23}$.

W celu umiejscowienia politycznych zabiegów Anny Luizy z lat 1764-1765 warto zakreślić zwięzły rys życia magnatki. Anna Luiza Mycielska przyszła na świat 22 października 1729 r. Była córką Macieja Mycielskiego h. Dołęga (1690-1747), starosty konińskiego, a od 1737 r. kasztelana poznańskiego, i Weroniki z Konarzewskich (1699-1762). Z tego małżeństwa dożyło wieku dorosłego pięć córek (prócz Anny Luizy były to Teresa, Weronika, Teofila i Józefa) ${ }^{24}$ i trzech synów (Józef, Stanisław i Jan Nepomucen) ${ }^{25}$.

Rodzina Mycielskich, odgrywająca znaczącą rolę polityczną w Wielkopolsce, zawdzięczała koligacje z Radziwiłłami Teofili z Leszczyńskich. Z jej pierwszego małżeństwa z Filipem Konarzewskim (zm. 1703) pochodziła bowiem Weronika, matka bohaterki niniejszego artykułu. Po śmierci męża Teofila wyszła wkrótce za Janusza Antoniego Wiśniowieckiego ${ }^{26}$. Z tego drugiego związku urodziła się w 1705 r. Franciszka Urszula, która w wieku 20 lat poślubiła Michała Kazimierza Radziwiłła „Rybeńkę”, wówczas ordynata nieświeskiego i starostę przemyskiego. Szybki wzrost znaczenia politycznego „Rybeńki” w pierwszym

${ }^{20}$ „Listy Anny Luizy z Mycielskich Radziwiłłowej”, AGAD, AR, IV, 612-621.

${ }^{21}$ „Diariusz Michała Kazimierza Radziwiłła [1702] 1719-1761. Kopia”, AGAD, AR, VI, II $-80 \mathrm{a}$, passim.

${ }^{22}$ A. Pawiński (red.), Pamiętniki Marcina Matuszewicza kasztelana brzeskiego-litewskiego 1714-1765, 4 tomy, Warszawa 1876, passim.

${ }^{23}$ Cenne materiały do biografii Anny Luizy znajdują się w dziale XI o nazwie „Dokumenty familijne”. Zob. AGAD, AR, XI, 156-157.

${ }^{24}$ Teresa wyszła za Józefa Skoroszewskiego, kasztelana przemęckiego. Wiktoria i Teofila wstąpiły do klasztoru Dominikanek we Lwowie, przyjmując imiona zakonne Pelagii i Genowefy. Józefa wyszła za Dymitra Aleksandra Jabłonowskiego, starostę kowelskiego. Zob. W. Szczygielski, Mycielski Maciej (1690-1747), [w:] E. Rostworowski (red.), PSB, 22, Wrocław-Warszawa i in. 1977, s. 342.

${ }^{25}$ Józef osiągnął urząd wojewody inowrocławskiego. Stanisław był starostą lubiatowskim, ale poświęcił się głównie pisarstwu. Wreszcie Jan Nepomucen był starostą ośnickim. Zob. W. Szczygielski, Mycielski Józef (1733-1789), ibidem, s. 336-337; E. Aleksandrowska, Mycielski Stanisław (1743-1818), ibidem, s. 346-347.

${ }^{26}$ I. Czamańska, Wiśniowieccy. Monografia rodu, Poznań 2007, s. 386. 
dziesięcioleciu panowania Augusta III $^{27}$ uczynił protekcję właścicieli Nieświeża szczególnie atrakcyjną dla krewnych.

Jako krewna Franciszki Urszuli, Anna Luiza utrzymywała kontakty z dworem nieświeskim, gdzie, dzięki zamiłowaniom literackim hetmanowej, mogła rozwinąć nie tylko pobożność, ale też znajomość języków (w tym przede wszystkim francuszczyzny) oraz zamiłowanie do poezji i teatru. To właśnie na dworze nieświeskim narodził się projekt mariażu Mycielskiej z Leonem Michałem Radziwiłłem, pogrobowym synem krajczego litewskiego i pana na Szydłowcu Michała Antoniego i Marcjanny z Siesickich. Podobnie jak Anna Luiza, ów przedstawiciel młodszej linii tzw. kleckiej rodu Radziwiłłów wychował się po śmierci matki w $1737 \mathrm{r}$. w kręgu nieświeskim ${ }^{28}$. Jako człowiek chorowity, ale szczerze oddany krewnym z Nieświeża, Leon Michał zawdzięczał „Rybeńce” stopień generała majora w wojsku litewskim, a od 1750 r. urząd strażnika polnego. Do zawarcia małżeństwa między Leonem Michałem a Anną Luizą doszło 16 lutego $1744 \mathrm{r}$. Związek ten nie trwał jednak długo: po siedmiu latach pożycia małżeńskiego 7 marca $1751 \mathrm{r}$. Leon Michał pożegnał się ze światem, pozostawiając trzech synów: Mikołaja (1746-1795), Michała i Macieja (1749-1800) oraz córkę Teofilę Magdalenę (ur. 1745). Na mocy testamentu nieboszczyka Anna Luiza wraz z potomstwem znalazła się pod opieką krewnych z Nieświe$\dot{z}^{29}$. Zgodnie $\mathrm{z}$ tradycją rodzinną po osiągnięciu przez dzieci wieku około sześciu lat wdowa powierzyła je „Rybeńce” i Franciszce Urszuli ${ }^{30}$.

Sytuacja rodzinna uległa zmianie wraz ze śmiercią hetmanowej, która nastąpiła 23 maja 1753 r. Mimo silnych uczuć, które łączyły „Rybeńkę” z Franciszką Urszulą ${ }^{31}$, wdowiec szybko zaczął myśleć o ponownym ożenku. Podczas gdy na pogrzeb, zaplanowany na 1 września, zaczynali zjeżdżać się goście, 28 sierp-

${ }^{27} \mathrm{~W} 1734$ r. Michał Kazimierz został marszałkiem nadwornym litewskim. Następnie zaawansował na urząd kasztelana trockiego (1736), wojewody trockiego (1737), kasztelana wileńskiego (1742) i wojewody wileńskiego (1744), dzierżąc jednocześnie buławę polną litewską (od 1736 r.), a następnie wielką (od 1744 roku). Zob. H. Dymnicka-Wołoszyńska, Radziwiłł Michał Kazimierz zw. Rybeńko (1702-1762), [w:] E. Rostworowski (red.), PSB, 30, Wrocław-Warszawa i in. 1987, s. 300-301.

${ }^{28}$ Zapis z 9 VI 1737, AGAD, AR, VI, II-80a, s. 833.

${ }^{29}$ Zapis z 7 III 1751, ibidem, s. 1778.

${ }^{30}$ Zapisy z 28 III 1751 i z 25 II 1753, ibidem, s. 1784, 1899.

${ }^{31}$ Ten związek małżeński został dogłębnie omówiony na podstawie korespondencji i zapisek diariuszowych przez Alojzego Sajkowskiego. Zob. A. Sajkowski, Staropolska miłość. Z dawnych listów i pamiętników, Poznań 1981, s. 225-262. 
nia na obiedzie u hetmana pojawiła się Anna Luiza. Pod tą datą „Rybeńko” notował: „Ten dzień mi jest pamiętny” ${ }^{32}$. Prawdopodobnie już wtedy wybór Michała Kazimierza padł na dwadzieścia siedem lat młodszą od niego wdowę. Intercyza ślubna została podpisana 4 grudnia $^{33}$, a szesnaście dni później hetman zanotował w diariuszu, że czeka tylko na dyspensę z Rzymu ${ }^{34}$. Ostatecznie ślub odbył się w dniu 12 stycznia 1754 r. w kościele Dominikanek we Lwowie. Warto zaznaczyć, że w klasztorze tym mieszkały zarówno siostry panny młodej Pelagia i Genowefa, jak też fundatorka, była teściowa „Rybeńki”, Teofila z Leszczyńskich Wiśniowiecka, która w 1753 r. porzuciła światowe życie, by spędzić ostatnie lata $\mathrm{w}$ modlitwie ${ }^{35}$. Mariaż Anny Luizy $\mathrm{z}$ hetmanem wielkim litewskim miał doniosłe skutki dla całej rodziny Mycielskich. Z protekcji Radziwiłła korzystali odtąd również młodsi bracia Mycielskiej - Józef, który na koszt hetmana odbył podróż zagraniczną i otrzymywał stopnie wojskowe, oraz Stanisław, który wychował się w Nieświeżu ${ }^{36}$.

Małżeństwo układało się dosyć dobrze, mimo że korespondencja nie świadczy o takiej zażyłości, jaka cechowała poprzedni związek hetmana. Para doczekała się licznego potomstwa. Pochodziły z tego mariażu cztery córki: Weronika, Barbara Jadwiga, Maria Wiktoria i Józefina oraz jeden chłopiec, Hieronim Wincenty, urodzony 11 maja 1759 r. ${ }^{37}$ Anna Luiza szybko stała się duszą rezydencji Radziwiłłów w Nieświeżu, gdzie kontynuowała tradycje teatru dworskiego. O ile pozwalały jej na to liczne ciąże, księżna występowała osobiście jako aktorka, jak w przypadku tragedii „Józefa patriarchy”, napisanej przez brata Stanisława ${ }^{38}$. Prestiż spływający ze związku z najbardziej wpływowym dostojnikiem Wielkiego Księstwa Litewskiego ułatwił otrzymanie austriackiego orderu Dam Krzyża Gwiaździstego w 1757 r. Jednocześnie Anna Luiza zajmowała się wychowaniem dzieci z pierwszego małżeństwa. Za staraniem jej i męża Mikołaj, Michał i Maciej zostali przyjęci w lutym

${ }^{32}$ Zapis z 28 IX 1753, AGAD, AR, VI, II-80a, s. 1924.

${ }^{33}$ H. Dymnicka-Wołoszyńska, Radziwiłłowa Anna Ludwika, s. 387.

${ }^{34}$ Zapis z 20 XII 1753, AGAD, AR, II-80a, s. 1941.

${ }^{35}$ Zob. T. Bernatowicz, „Akt bardzo rzadko praktykowany”. Uroczystość obłóczyn księżnej Teofili z Leszczyńskich Wiśnowieckej we Lwowie, [w:] T. Bernatowicz (red.), Polska i Europa w dobie nowożytnej. Księga pamiątkowa dedykowana Profesorowi Juliuszowi A. Chrościckiemu, Warszawa 2009, s. 325-332.

${ }^{36}$ W. Szczygielski, Mycielski Józef, s. 336; E. Aleksandrowska, Mycielski Stanisław, s. 346.

${ }^{37}$ H. Dymnicka-Wołoszyńska, Radziwiłł Michał Kazimierz, s. 305.

${ }^{38}$ Zapis z 19 III 1756, AGAD, AR, VI, II-80a, s. 2070. 
1758 r. do jezuickiego kolegium szlacheckiego w Wilnie, gdzie kształcili się pod kierunkiem umyślnie sprowadzonego z Warszawy pedagoga Mikołaja Kossowskiego ${ }^{39}$.

Zmiany w życiu Anny Luizy rozpoczęły się wraz ze śmiercią hetmana, która nastąpiła 22 maja 1762 r. Magnatka postanowiła pozostać w stanie wdowim, przyjmując formalną opiekę zaledwie pięć lat młodszego pasierba Karola Stanisława „Panie Kochanku” nad sobą i nieletnim potomstwem. Rezydowała wtedy w Mirze, w odległości ok. 20 kilometrów od stolicy ordynackiej. Kontakty z nowym nestorem rodu Radziwiłłów układały się bez zarzutu i już 2 sierpnia 1762 r. „Panie Kochanku” zatwierdził wszystkie zapisy ojca na rzecz wdowy. W zakresie edukacji synów z pierwszego związku Anna Luiza zachowała daleko idącą autonomię, o czym świadczy fakt, że samodzielnie podejmowała starania o przyjęcie ich do jezuickiego Collegium Nobilium w Warszawie w przekonaniu, że poziom nauczania będzie tam wyższy ${ }^{40}$. Wkrótce wraz ze śmiercią króla Augusta III uległa zmianie koniunktura polityczna. W wyniku opozycji Karola Stanisława wobec planów elekcji Poniatowskiego rozpoczął się okres wygnania nie tylko dla samego przywódcy rodu, ale również dla jego macochy.

Walki o sukcesję tronu w Rzeczypospolitej po zgonie ostatniego Wettyna (5 października 1763 r.) rozpoczęły się początkowo bez udziału „Panie Kochanku”. Karol Stanisław, mimo że zdecydowanie przeciwny dążącym w kierunku elekcyjnego sukcesu książętom Czartoryskim, oraz ich siostrzeńcowi Stanisławowi Antoniemu Poniatowskiemu, początkowo nie angażował się w wydarzenia bezkrólewia i kontynuował dawny hulaszczy tryb życia ${ }^{41}$. Obojętność wobec przygotowań czynionych przez obóz Czartoryskich przejawiała również Anna Luiza w swoich listach do pasierba, gdy wciąż wydawało się, że może dojść do współpracy pomiędzy nim a hetmanem Michałem Józefem Massalskim ${ }^{42}$. $\mathrm{W}$ związku z biernością księcia jeszcze w lutym posłowie rosyjscy w Rzeczy-

${ }^{39}$ Kurier Polski 10, 1758, Wilno, 22 II 1758. Tu najstarszy z synów przywitał po francusku księcia kurlandzkiego Karola Krystiana Wettyna. Zob. Diarium Collegii Academici Societatis Iesu 1752-1766, Lietuvos Valstybès Istorijos Archivas, 1135, 20, 303, k. 115v-116.

${ }^{40}$ A.L. Radziwiłłowa do K.S. Radziwiłła, Mir, 22 II 1764, AGAD, AR, IV, 619, s. 78.

${ }^{41}$ J. Michalski, Radziwiłł Karol Stanisław zw. Panie Kochanku (1734-1790), [w:] E. Rostworowski (red.), PSB, 30, s. 250.

${ }^{42} \mathrm{O}$ próbach kierowania sejmiku wiłkomirskiego za pośrednictwem Siesickich wzmiankowała hetmanowa dopiero pod koniec stycznia 1764 r. Zob. A.L. Radziwiłłowa do K.S. Radziwiłła, Mir, 21 I 1764, AGAD, AR, IV, 619, s. 60. 
pospolitej liczyli na możliwość przekonania wojewody wileńskiego do opcji prorosyjskiej w czasie nadchodzącej elekcji ${ }^{43}$. Dopiero porażki poniesione przy wyborze posłów na sejm konwokacyjny oraz sędziów na trybunały kapturowe w Wielkim Księstwie Litewskim na początku 1764 r. zmobilizowały Radziwiłła do większej aktywności ${ }^{44}$. Próba odzyskania inicjatywy poprzez przeprowadzenie zmiany legalnie już wybranych sędziów kapturowych nie obyła się jednak bez licznych nadużyć oraz gwałtów ze strony księcia Radziwiłła, który najważniejszego ze swoich adwersarzy politycznych, biskupa Ignacego Massalskiego, postanowił obsypać pogróżkami i obelgami w jego własnym pałacu ${ }^{45}$. Te niezręczne posunięcia posłużyły „Familii” Czartoryskich jako pretekst, aby otwarcie działać przeciwko Radziwiłłowi, a nawet posłużyć się popełnianymi przez niego nadużyciami jako pretekstem do zawiązania przygotowywanej już wcześniej konfederacji na Litwie, która teraz miała funkcjonować oficjalnie w celu obrony zagrożonych przez gwałtownego magnata wolności ${ }^{46}$. Poczynania Karola Stanisława stanowiły także wygodny pretekst dla książąt Czartoryskich do wezwania wojsk Katarzyny II w celu obrony projektowanej konfederacji ${ }^{77}$. Sam akt konfederacji był skierowany właśnie przeciwko dziedzicowi Nieświeża i zawierał wyliczenia wszystkich nadużyć, jakich książę ten miał dopuścić się $\mathrm{w}$ toku bezkrólewia ${ }^{48}$. Wezwane na pomoc przez konfederację litewską wojska rosyjskie działały otwarcie przeciwko Radziwiłłowi, który według oponentów swoim zachowaniem miał zagrażać swobodom i wolnościom Rzeczypospolitej ${ }^{49}$. W ciągu całego okresu bezkrólewia obie strony stale posługiwały się figurą „zagrożonych wolności” jako użytecznej propagandowo broni przeciwko adwersarzom politycznym.

Tymczasem na przełomie kwietnia i maja 1764 r. Karol Stanisław podjął, wspólnie z nieformalnym przywódcą stronnictwa sasko-hetmańskiego (zwanego również republikańskim lub patriotycznym) Janem Klemensem Branickim, nieudaną próbę przeciwdziałania zabiegom Czartoryskich. Mimo że obaj

${ }^{43}$ Z. Zielińska, Polska w okowach „systemu północnego” 1763-1766, Kraków 2012, s. 86.

${ }^{44}$ J. Michalski, Radziwiłł Karol Stanisław, s. 250.

${ }^{45}$ Z. Zielińska, Polska w okowach, s. 90; A. Pawiński (red.), Pamiętniki Marcina Matuszewicza, IV, s. 199-200.

${ }^{46}$ Z. Zielińska, Polska w okowach, s. 90.

${ }^{47}$ Zawiązanej ostatecznie 16 kwietnia 1764 r., zob. ibidem, s. 91-93.

${ }^{48}$ J. Michalski, Radziwiłł Karol Stanisław, s. 250.

${ }^{49}$ Z. Zielińska, Polska w okowach, s. 123-124. 
magnaci przybyli do Warszawy z własną milicją, postanowili oni zaprotestować przeciwko obecności wojsk rosyjskich w Polsce, apelując do prymasa interreksa Władysława Łubieńskiego o zwołanie pospolitego ruszenia i odroczenie konwokacji. Następnie rozesłali już niepodpisany przez prymasa oficjalny protest $\mathrm{w}$ tej sprawie do najważniejszych stolic europejskich ${ }^{50}$. W związku z niepowodzeniem tej próby słabnący republikanie złożyli 7 maja 1764 r. manifest przeciwko rozpoczynającemu się sejmowi konwokacyjnemu i opuścili stolicę. Ten jednak, związany węzłem konfederacji, nie uległ zerwaniu i kontynuował pracę $\mathrm{w}$ duchu reform projektowanych przez Czartoryskich. W toku kolejnych gwałtów i nadużyć milicja radziwiłłowska doprowadziła do spalenia Terespola, miasta stanowiącego posiadłość stronnika Czartoryskich Jerzego Detloffa Flemminga, podskarbiego wielkiego litewskiego. Następnie żołnierze wojewody wileńskiego ponieśli porażkę $\mathrm{w}$ starciu z wojskami rosyjskimi pod Słonimiem 26 czerwca 1764 r. $^{51}$. Zmuszony do odwrotu Karol Stanisław, umykając przed oddziałami carskimi, zbiegł ostatecznie za granicę turecką 14 lipca, rozpoczynając trzyletni okres emigracji i opozycji wobec nowego króla Stanisława Augusta, wybranego jednomyślnie, choć w asyście wojsk carskich, dwa miesiące po tych wydarzeniach.

Pokonany obóz ulegał w ciągu kolejnych miesięcy coraz większemu rozproszeniu i destabilizacji52 ${ }^{5}$. Część dawnych stronników Radziwiłła, która pozostała w kraju, przeszła na stronę Czartoryskich ${ }^{53}$. W oczekiwaniu na zasiłki pieniężne z zagranicy, a potem już tylko na mediację przychylnych mocarstw, a więc przeciwnych Rosji i Prusom katolickich dworów „południa” (Francji, Austrii, Hiszpanii oraz zaprzyjaźnionej Saksonii), Branicki i Radziwiłł pozostawali na terytorium Węgier i Turcji, skąd zabiegali o poparcie Wersalu, Wiednia oraz Drezna dla odzyskania swoich urzędów i majątków ${ }^{54}$.

${ }^{50}$ Ibidem, s. 95.

${ }^{51}$ J. Michalski, Radziwiłł Karol Stanisław, s. 250.

${ }^{52}$ Zawiedzione zostały również nadzieje „patriotów” na pomoc Fryderyka II. Zob. ibidem, s. 250; Z. Zielińska, Polska w okowach, s. 156-157.

${ }^{53}$ Należy do nich zaliczyć również brata hetmanowej Józefa Mycielskiego, który podpisał elekcję Stanisława Augusta. Zob. W. Szczygielski, Mycielski Józef, s. 336.

${ }^{54}$ Jeszcze w czerwcu niechętna zrywaniu stosunków z Polską Austria próbowała poprzez ambasadora Mercy d’Argenteau na miejscu dokonać mediacji i przywrócenia Branickiego i Radziwiłła w dobrach i na urzędach. Warunki tej mediacji zostały jednak odrzucone przez Czartoryskich. Zob. Z. Zielińska, Polska w okowach, s. 159. Następnie do Wiednia posłował z ramienia Branickiego ksiądz Wacław Antoni Betański. Zob. ibidem, s. 171. 
W międzyczasie opuszczone przez Karola Stanisława dobra radziwiłłowskie zostały już w czerwcu 1764 r. zajęte przez wojska rosyjskie generała Joana Grigoriewicza Rennenkampfa ${ }^{55}$, a następnie zasekwestrowane przez konfederację litewską w sierpniu $1764 \mathrm{r}$. Zmusiło to lojalną w stosunku do pasierba Annę Luizę do udania się do Gdańska, prawdziwego azylu dla powiązanych z pokonanymi przez „Familię” przedstawicielek płci pięknej ${ }^{56}$. Pierwsze plany wyjazdu księżna poruszyła w korespondencji z pasierbem już w marcu tego roku, gdy rozeszły się pierwsze wieści o przemarszu wojsk rosyjskich i kraj stanął na krawędzi wojny domowej ${ }^{57}$. Księżna wyraziła wtedy obawę, że dzieci zostaną jej odebrane, czemu właśnie wyjazd mógłby zapobiec. Pierwotna koncepcja zakładała przeniesienie się do starostwa człuchowskiego, na pograniczu z państwem brandenburskim, skąd Radziwiłłowa mogłaby zabiegać o protekcję Fryderyka II ${ }^{58}$. Ostatecznie jednak Anna Luiza wybrała nadbałtycką metropolię, mając na uwadze jej neutralność w toczącym się konflikcie ${ }^{59}$. Tam też Radziwiłłowie posiadali pałac od $1736 \mathrm{r}^{60}$ Synowie z pierwszego małżeństwa pozostawali natomiast cały czas w Polsce: Mikołaj, Michał i Maciej kształcili się w jezuickim kolegium szlacheckim w Warszawie, gdzie też brali udział w popisach szkolnych ${ }^{61}$.

${ }^{55}$ Ibidem, s. 158.

${ }^{56} \mathrm{~W}$ relacjach Dumonta oprócz Anny Luizy Radziwiłłowej pojawiają się księżna Anna Paulina z Sapiehów Jabłonowska oraz księżna Sanguszkowa, zapewne Konstancja z Denhoffów, żona Janusza Aleksandra Sanguszki. Zob. M. Czeppe, R. Marcinek, Sanguszkowa z Denhoffów, 2.v. Rogalińska Konstancja Kolumba (1716-1791), [w:] H. Markiewicz (red.), PSB, 34, Wrocław-Warszawa i in. 1992-1993, s. 523. Na temat życia szlachty w metropolii nadbałtyckiej u schyłku panowania Augusta III zob. J. Dygdała, Z życia towarzyskiego polskich elit szlachecko-magnackich w Gdańsku w połowie 1757 r. (Przebendowscy, Adam Kazimierz Czartoryski i wielu innych), [w:] T. Kostkiewiczowa (red.), Przyjemności w kulturze epoki rozumu, Warszawa 2011, s. 207-219.

${ }^{57}$ A.L. Radziwiłłowa do K.S. Radziwiłła, Mir, 31 III 1764, AGAD, AR, IV, 620, s. 89.

${ }^{58}$ Ibidem, s. 91.

${ }^{59}$ „Mam pewną wiadomość, że miasto Gdańsk w teraźniejszych koniunkturach obojętność do żadnej nie przyłączając się strony zachowywać będzie”. Zob. A.L. Radziwiłłowa do K.S. Radziwiłła, Mir, 16 IV 1764, ibidem, s. 97.

${ }^{60}$ W. Karkucińska, Anna Katarzyna z Sanguszków Radziwiłłowa (1676-1746): działalność gospodarcza i mecenat, Warszawa 2000, s. 64-65.

${ }^{61}$ Michał i Maciej wymieni byli w broszurze pt. „Exercices sur les différents objets d'études qui ont occupé pendant le cours de l'année les élèves du collège des nobles de Varsovie de la Compagnie de Jésus", datowanej prawdopodobnie na rok 1766. O ich obecności w stolicy świadczy też metryka listów Mikołaja. Zob. AGAD, AR, IV, 540, s. 1-4. 
Anna Luiza starała się trzymać ich z dala od polityki: w przededniu konwokacji z trudem zgodziła się na to, aby najstarszy Mikołaj starał się o mandat poselski na sejmiku pruskim ${ }^{62}$. Trzy lata później błagała pasierba, aby nie wymuszał na Macieju i Mikołaju wystąpienia na sejmie skonfederowanym, zwanym później repninowskim, „bo trzeba albo przeciwko Moskwie iść, albo przeciwko ojczyźnie"63.

Pierwsza wzmianka o obecności Anny Luizy w Gdańsku pojawia się w depeszach francuskiego konsula Dumonta do księcia de Praslin na początku sierpnia 1764 r. ${ }^{64}$, a więc na miesiąc przed elekcją Stanisława Augusta (7 września). Wedle francuskiego posła Radziwiłłowa wraz z dziećmi z drugiego małżeństwa przybyła właśnie do Gdańska, aby tu przeczekać niespokojny czas nadchodzącej elekcji („le temps des troubles”) ${ }^{65}$. Od tego momentu Anna Luiza rozpoczęła, podobnie jak jej pasierb i opiekun, trudny czas tułaczki w oczekiwaniu na rozwój wydarzeń. Francuski konsul w Gdańsku był naturalnym adresatem macochy szukającej mediacji w intencji wygnanego pasierba, wobec którego postanowiła pozostać lojalna. Sam Dumont stał się ponadto źródłem doniesień dla księżnej, odciętej od wszelkich informacji na temat rozwoju sytuacji międzynarodowej.

Już w liście z pierwszego września 1764 r. francuski konsul donosił o reakcji Radziwiłłowej na zasekwestrowanie dóbr Karola Stanisława i pozbawienie go urzędu wojewody wileńskiego przez konfederację litewską na mocy de-

${ }^{62}$ A.L. Radziwiłłowa do K.S. Radziwiłła, Mir, 22 II 1764, AGAD, AR, IV, 620, s. 78. Powodów tej inicjatywy należy doszukiwać w sytuacji zaistniałej po przegranej przez Radziwiłłów kampanii wyborczej do sejmików kapturowych i do sejmu konwokacyjnego. Aby jeszcze wpłynąć na skład nadchodzącego sejmu, obóz republikański usiłował doprowadzić do elekcji jak największej liczby stronników na sejmiku generalnym pruskim w Grudziądzu, gdzie liczba posłów nie była określona przez prawo.

${ }^{63}$ A.L. Radziwiłłowa do K.S. Radziwiłła, Drezno, 5 IX 1767, ibidem, s. 193.

${ }^{64}$ Dumont pozostawał już wtedy ostatnim przedstawicielem Francji na terytorium Rzeczypospolitej, po scysji między ambasadorem de Paulmy a prymasem Władysławem Łubieńskim (7 czerwca 1764 r.), która spowodowała zerwanie stosunków polsko-francuskich i nieoczekiwanie zmusiła również pozostałych dyplomatów Wersalu (rezydenta Pierre-Michela Hennina oraz konsula Jean-Antoine’a Moneta) do wyjazdu z Rzeczypospolitej. Solidarnie z Francją musiały postąpić niechętna takiemu rozwiązaniu Austria (ambasador Florimond-Claude Mercy d'Argenteau i rezydent Gottfried van Swieten), oraz lojalna Wettynom Hiszpania (rezydent José Onis). Dumont, jako rezydent króla Francji oraz konsul narodu francuskiego akredytowany przy senacie miasta Gdańska, nie był zobligowany do wyjazdu.

${ }^{65}$ J.F. Dumont do ks. de Praslin, Dantzick, 11 VIII 1764, AMAE, CP Dantzig 21, k. 146. 
kretu z 16 sierpnia ${ }^{66}$. Anna Luiza miała być przerażona tym aktem przemocy, przeczuwając, że teraz Czartoryscy najpewniej zwrócą się przeciwko niej i jej własnym dzieciom, aby to na nich dokonać zemsty za nieuchwytnego, bo przebywającego na emigracji „Panie Kochanku”67. Szczególnie zagrożony miał być najmłodszy syn, pięcioletni Hieronim Wincenty, który w sytuacji nieobecności nestora rodu pozostawał bez prawnego opiekuna. Anna Luiza nie uznawała bowiem decyzji konfederacji litewskiej, na mocy której w sierpniu 1764 r. na tutorów jej syna wyznaczono ludzi związanych z „Familią" Czartoryskich ${ }^{68}$. Obawa przed odebraniem dziecka przez radziwiłłowskich nieprzyjaciół w celu manipulacji politycznych oraz lojalność wobec prawowitego opiekuna-pasierba skłoniły Annę Luizę do podjęcia aktywności dyplomatycznej na własną rękę.

Jeszcze przed elekcją Stanisława Augusta, na początku września 1764 r., macocha Karola Stanisława zwróciła się z prośbą do konsula Dumonta o przekazanie własnoręcznej korespondencji adresowanej do Ludwika XV, ministra spraw zagranicznych Francji, księcia de Praslin oraz niedawnego ambasadora Wersalu w Polsce, markiza de Paulmy, z prośbą o mediację mocarstw w sprawie pasierba. Równocześnie z apelem o pomoc do dworu francuskiego Anna Luiza zwróciła się listownie do cesarzowej Marii Teresy, pełniącego obowiązki regenta elektoratu Saksonii królewicza Ksawerego, jego brata Karola, księcia Kurlandii, oraz bratowej, elektorowej wdowy, Marii Antonii ${ }^{69}$. Z ramienia hetmanowej z misją doręczenia tej korespondencji

${ }^{66}$ Dekretem tym konfederacja litewska odbierała Karolowi Stanisławowi urząd wojewody wileńskiego, sekwestrowała majątki na Litwie do momentu spłacenia wszystkich długów i ogłaszała go wrogiem ojczyzny. Zob. J. Michalski, Radziwiłł Karol Stanisław, s. 251; Z. Zielińska, Polska w okowach, s. 173.

${ }^{67}$ J.F. Dumont do ks. de Praslin, Dantzick, 1 IX 1764, AMAE, CP Dantzig 21, k. 164-165.

${ }^{68} \mathrm{~J}$. Michalski, Radziwiłł Karol Stanisław, s. 251.

${ }^{69}$ Adresatów pozostałych listów Anny Luizy wymienia Dumont w liście z 1 IX 1764, AMAE, CP Dantzig 21, k. 165. Zob. listy A.L. Radziwiłłowej, bez daty i miejsca (prawdopodobnie Gdańsk, 1 IX 1764), do królewicza Ksawerego w zbiorach Biblioteki Polskiej w Paryżu (BPP 74/7, s. 1585-1588) oraz do elektorowej Marii Antonii w zbiorach Głównego Archiwum Państwowego w Dreźnie (SHSA, 10026 Geheimes Kabinett, 3691/1, k. 413). W liście do Ksawerego Radziwiłłowa odmalowywała obraz pasierba jako utrapionego zwolennika szczęśliwych rządów saskich w Polsce oraz niedoszłego wyborcę samego królewicza. List do Marii Antonii jest bardzo podobny w treści do listu adresowanego do króla Francji. W swojej odpowiedzi z 21 września Maria Antonia nazywała Annę Luizę „przyjaciółką” i obiecywała wesprzeć wszelkie zabiegi swojego szwagra, pełniącego obowiązki regenta Saksonii, w kwestii 
oraz zabiegania o poparcie dla sprawy Radziwiłłów udał się do Drezna, a następnie do Wiednia kosmopolityczny agent Charles de Saint Pol ${ }^{70}$.

Anna Luiza rozpoczyna swój list do Ludwika XV, pisząc o sobie w trzeciej osobie poprzez zastosowanie figury zrozpaczonej matki („mère éplorée”), która przerażona wrogimi poczynaniami „Familii” wobec rzekomo winnego wyłącznie miłości do ojczyzny pasierba i w obawie o bezpieczeństwo swoich własnych dzieci musi odwołać się do życzliwej protekcji zapowiedzianej przez Wersal w deklaracji z 16 marca $1764 \mathrm{r}^{71}$ Radziwiłłowa nie bez racji powoływała się właśnie na obietnice złożone przez Francję w dokumencie wręczonym przez markiza de Paulmy prymasowi Łubieńskiemu podczas bezkrólewia. Mimo że było to pismo niedatowane i niepodpisane przez samego Ludwika XV, to Wersal deklarował w nim pomoc w wypadku zagrożenia polskich wolności, a za takowych obrońcę Francja powinna była, wedle Radziwiłłowej, uznać współpracującego z Branickim Karola Stanisława „Panie Kochanku”. W dalszej części listu do króla Francji Anna Luiza odmalowała obraz materialnej ruiny domu radzi-

Radziwiłłów na dworach Wiednia i Wersalu. Zob. brulion listu Marii Antonii, Dresden, 21 IX 1764, ibidem, k. 412.

${ }^{70}$ Przebieg misji Saint Pola dokładnie śledzili francuscy dyplomaci: minister pełnomocny Wersalu przy dworze saskim François-Antoine baron de Zuckmantel oraz sekretarz francuskiego poselstwa w Wiedniu Conrad-Alexandre Gérard. Zwłaszcza ten pierwszy poświęcił wiele miejsca przebiegowi misji Saint Pola w swej relacji do dworu francuskiego, którą warto tu przytoczyć w całości: „Il est arrivé ici de Dantzig il y a quelques jours, un certain Baron de St. Pol qui a été longtems attaché au feu grand général père du Prince Palatin de Vilna, et qui est revêtu du titre de Colonel au service de Saxe. Il est envoyé de la part de la belle-mère de ce Prince pour exposer à la Cour de Dresde la triste situation où se trouve son fils et pour la solliciter de luy accorder l'assistance que son zèle et son attachement pour les Princes de la Maison de Saxe semblent luy promettre. Ce gentilhomme a été bien reçu, on a été touché du sort du Prince Radziwill et on a promis de l'assister. Mais comme M. de St. Pol étoit en même tems chargé de se rendre à Vienne pour y exécuter la même commission qu'icy on l'a pressé de s'y rendre; et ce ne sera, à ce qui paroît, qu'en conséquence du parti que prendra la Cour de Vienne que celle de Dresde spécifiera l'espèce d'assistance qu'elle pourra donner au Prince Radziwill. Il est à croire que M. de St. Pol parviendra à émouvoir ces deux Cours en faveur de ce Prince, qui n'est malheureux que parce qu'il aime sa patrie, qu'il ose en défendre la liberté, et surtout parce qu'il est riche et puissant". Zob. baron de Zuckmantel do ks. de Praslin, Dresden, 18 IX 1764, AMAE, CP Saxe 50, k. 292-293. Inny punkt widzenia prezentował niechętny sprawie Radziwiłłów Gérard: „Le Cte de St. Pol vient d’arriver icy, il est chargé par la mère [sic!] du prince Radziwill de solliciter la Cour de Vienne de s'intéresser à son sort et à luy accorder quelques secours. Je suis prévenu qu'il réclamera mon assistance, mais j’aurai un grand soin, Mgr., de ne rien faire au délà des intentions que vous m’avez fait connoître [...]”. Zob. C.A. Gérard do ks. de Praslin, Vienne, 22 IX 1764, AMAE, CP Autriche 299, k. 375-376.

${ }^{71}$ A.L. Radziwiłłowa do Ludwika XV, Dantzick, 1 IX 1764, AMAE, CP Dantzig 21, k. 166. 
wiłłowskiego, którego jedynym do tej pory przewinieniem miało być całkowite oddanie właśnie Francji, co z kolei miało wzbudzić zrozumiałą wściekłość Rosji, jako potęgi zazdrosnej o wielkość i chwałę monarchii Burbonów ${ }^{72}$. Księżna podkreślała ponadto, że zawsze oddanym Wersalowi Radziwiłłom grozi teraz zupełna ruina i upadek, co, w domyśle, dla Francji miałoby oznaczać utratę ważnego stronnika ${ }^{73}$.

Kolejny list, pod tą samą datą, Anna Luiza adresowała również do samego markiza de Paulmy, który 16 marca 1764 r. wręczył prymasowi wspomnianą deklarację. Radziwiłłowa informowała byłego ambasadora francuskiego w Polsce o przebiegu wypadków politycznych, jakie miały miejsce po wyjeździe dyplomaty w czerwcu $1764 \mathrm{r}$. Wedle tej relacji prześladowany przez wojska rosyjskie Karol Stanisław miał być zmuszony do szukania schronienia u hospodara mołdawskiego, a jego dobra miały być rozdawane według uznania książąt Czartoryskich, których wściekłości i żądzy zemsty już nic nie mogło zahamować ${ }^{74}$. Najlepszym dowodem na potwierdzenie słów Anny Luizy miał być właśnie sierpniowy dekret konfederacji litewskiej, w którym „Panie Kochanku” ogłaszano wrogiem ojczyzny. Wedle macochy w związku z brakiem podstaw do zarzucanych jej pasierbowi czynów dekret Czartoryskich miał być umotywowany tylko ślepym pragnieniem zniszczenia wojewody wileńskiego. Sąd konfederacji litewskiej miał wedle macochy być nieobiektywny wobec jej pasierba, bo sterowany przez wrogich Czartoryskich. Anna Luiza przyznawała, że Karol Stanisław uciekł się do przemocy podczas bezkrólewia, ale tylko w celu obrony ojczyzny, i że jest gotowy poddać się osądowi wydanemu przez organ niezależny od „Familii”. Radziwiłłowa nie bez racji kierowała swoje prośby do tego dyplomaty francuskiego, który w imieniu swego dworu prezentował w Warszawie wspomnianą już deklarację Wersalu z 16 marca $1764 \mathrm{r}^{75}$ Apelując do markiza de Paulmy, Anna Luiza zwracała się bezpośrednio do tego, który swoim podpisem gwarantował wspomnianą deklarację oraz obiecywał realizację zobowiązań. Do obrazu ruiny radziwiłłowskich majątków, zarysowanego

\footnotetext{
${ }^{72}$ Ibidem.

${ }^{73}$ Ibidem.

${ }^{74}$ A.L. Radziwiłłowa do markiza de Paulmy, Dantzick, 1 IX 1764, AMAE, CP Pologne 285, k. 221-222.

${ }^{75}$ Podpis markiza de Paulmy widnieje na egzemplarzu francuskiej deklaracji wręczonej prymasowi Łubieńskiemu przez ambasadora. Zob. „Déclaration” w zbiorze „Papiery prymasa Łubieńskiego z lat 1763-1764 dotyczące ostatniego bezkrólewia”, BPP 33/3, s. 253-256.
} 
już w liście do króla Francji, wdowa dodawała tym razem kwestię rozkradanych w Słucku i Nieświeżu bezcennych archiwów rodziny ${ }^{76}$.

Po otrzymaniu korespondencji z Gdańska książę de Praslin przedłożył królowi Francji list Anny Luizy ${ }^{77}$. Przed sporządzeniem odpowiedzi minister polecił Dumontowi przekazanie Radziwiłłowej zapewnień o niezmiennej życzliwości oraz protekcji Wersalu nad związanymi z Francją magnatami, z zastrzeżeniem, że tylko dalszy rozwój wydarzeń pozwoli uczynić mediację mocarstw w imieniu „patriotów” bardziej efektywną („les circonstances seules peuvent développer les moyens de leur rendre cet apui plus utile") ${ }^{78}$. Chodziło o moment, w którym Stanisław August zacznie zabiegać o uznanie swojej elekcji przez państwa „południa”. Wtedy planowano przedstawić nowemu królowi szereg warunków do spełnienia, w tym ten dotyczący repatriacji członków republikańskiej opozycji, a więc przede wszystkim Branickiego, a może i Radziwiłła ${ }^{79}$.

W październiku Dumont przekazał hetmanowej treść listu swojego przełożonego, która miała przyjąć te zapewnienia z niewymowną satysfakcją („,avec une satisfaction inexprimable"), tym bardziej że podobne wdowa otrzymała już ze strony dworów w Wiedniu i Dreźnie ${ }^{80}$. Tym, co jednak miało dalej trapić

${ }^{76}$ A.L. Radziwiłłowa do markiza de Paulmy, Dantzick, 1 IX 1764, AMAE, CP Pologne 285, k. 221-222.

${ }^{77}$ Sam minister był błagany przez Radziwiłłową, aby zechciał przedłożyć królowi Francji jej list oraz wysłuchać relacji markiza de Paulmy odnośnie do wypadków w Polsce i w konsekwencji pochylić się nad niesprawiedliwością, jaka dotknęła rzekomo bardzo oddaną Wersalowi rodzinę Radziwiłłów, a w szczególności Karola Stanisława. Zob. A.L. Radziwiłłowa do ks. de Praslin, Dantzick, 1 IX 1764, AMAE, CP Pologne 288, k. 38.

${ }^{78}$ Ks. de Praslin do J.F. Dumont, Versailles, brulion listu z 23 IX 1764, AMAE, CP Dantzig 21, k. 181.

${ }^{79}$ Choć ks. de Praslin wyraźnie dystansował się od groteskowej postaci Karola Stanisława, wykluczając go zupełnie z grona stronników Wersalu, to ostatecznie francuski ambasador w Wiedniu, Louis Marie Florent hrabia du Châtelet, otrzymał instrukcję o podjęciu sprawy Radziwiłła podczas rozmów o uznanie majestatu Stanisława Augusta przez mocarstwa „południa”. Zob. ks. de Praslin do du Châtelet, Versailles, brulion listu z 25 I 1765, AMAE, CP Autriche 301, k. 92-93.

${ }^{80}$ J.F. Dumont do ks. de Praslin, Dantzick, 13 X 1764, AMAE, CP Dantzig 21, k. 195. Dwór saski rzeczywiście wielokrotnie podejmował się zabiegów o uzyskanie poparcia Wersalu, Wiednia, a nawet Madrytu dla sprawy Radziwiłłów. Saski minister Karl Flemming postulował o włączenie dossier „Panie Kochanku” do warunków dotyczących uznania Stanisława Augusta przez Francję bezpośrednio u barona de Zuckmantel w Dreźnie, jak i poprzez posła nadzwyczajnego Saksonii w Wersalu, Gaspard-François Belona, generała de Fontenay. Zob. relację nawiązującą do apeli Anny Luizy z Gdańska, K. Flemming do gen. de Fontenay, Dresde, 25 XI 1764, SHSA, 10026 Geheimes Kabinett, 2744/4, k. 544-545. 
Annę Luizę, była niepewna sytuacja pasierba w związku z brakiem wieści od „Panie Kochanku”81. Jednocześnie sytuacja macochy pogarszała się w związku z szykanami konfederacji litewskiej, która miała realizować postanowienia sierpniowego dekretu przeciwko Radziwiłłowi, licząc na zupełne zniszczenie tej rodziny na Litwie. Z tego powodu dobra, z których Anna Luiza miała prawo czerpać dochody, miały być zagrożone zajęciem i zrabowaniem przez wojska rosyjskie, co jednak wedle relacji Dumonta wcale nie złamało jej ducha („ne l'a point abbatue”) ${ }^{82}$. Mimo uciekania się do takich środków przez stronę przeciwną Radziwiłłowa gotowa była wytrwać w oporze i spokojnie czekać na mediację mocarstw „południa”, rezygnując ze składania upokarzających skarg przed dworami Warszawy i Petersburga ${ }^{83}$.

W międzyczasie do Anny Luizy dochodziły również informacje o bardzo złej sytuacji finansowej pasierba, który, przebywając na emigracji, miał być pozbawiony wszelkich dochodów, a nawet wartościowych przedmiotów, które zdołał wcześniej zabrać ze sobą z Nieświeża. O wsparcie finansowe „Panie Kochanku” prosił Annę Luizę poprzez zaufanego kuriera Jan Klemens Branic$\mathrm{ki}^{84}$. W odpowiedzi na tę prośbę macocha przesłała pasierbowi tysiąc dukatów $\mathrm{z}$ dóbr, jakie posiadała na granicy z Węgrami ${ }^{85}$.

W końcu, 31 października 1764 r., książę de Praslin przesłał Dumontowi odpowiedź na wcześniejsze listy Anny Luizy, jednak tylko od markiza de Paulmy. Sam Ludwik XV oraz jego minister ograniczyli się, pomimo wcześniejszych obietnic, do werbalnych zapewnień przekazanych już macosze „Panie Kochanku” poprzez konsula w Gdańsku ${ }^{86}$. Wyręczając się w ten sposób osobą markiza, który publicznie objaśniał wykładnię deklaracji podczas bezkrólewia, Praslin decydował się nie odpowiadać na listy nawiązujące do dokumentu, który sam polecił swojemu podwładnemu prezentować w Warszawie w marcu 1764 r. Brulion listu odpowiedzi do Anny Luizy od markiza de Paulmy nie zachował się wśród

\footnotetext{
${ }^{81}$ Anna Luiza obawiała się ponadto, aby Karol Stanisław nie podjął w tym samym czasie kroków mogących pokrzyżować jej zabiegi w związku z brakiem komunikacji. Zob. AMAE, CP Dantzig 21, k. 195.

${ }^{82}$ Ibidem, k. 196.

${ }^{83}$ „Elle met toute sa confiance dans l'appuy des Cours auxquelles elle s'est adressée [...]”. Ibidem, k. 196-197.

${ }^{84}$ Zob. kopia listu hetmana J.K. Branickiego do A.L. Radziwiłłowej, Białystok, 30 X 1764, ibidem, k. 215.

${ }^{85}$ J.F. Dumont do ks. de Praslin, Dantzick, 21 XI 1764, ibidem, k. 229.

${ }^{86}$ Ks. de Praslin do J.F. Dumonta, Fontainebleau, brulion listu z 31 X 1764, ibidem, k. 216.
} 
materiałów z Ministerstwa Spraw Zagranicznych. Posiadamy natomiast kolejną relację Dumonta, który zdawał sprawozdanie z reakcji Radziwiłłowej na otrzymaną w końcu odpowiedź. Konsul bardzo śpieszył się z wręczeniem rzeczonego listu, ponieważ macocha „Panie Kochanku” miała już wielokrotnie dawać mu do zrozumienia, że dotychczasowy brak odpowiedzi bardzo ją niepokoi1 ${ }^{87}$. List markiza de Paulmy, w którym niedawny ambasador francuski w Polsce obiecywał poparcie swojego dworu proporcjonalne do trudnej sytuacji Radziwiłłów, uspokoił Annę Luizę ${ }^{88}$ Księżna dawała jednak francuskiemu konsulowi do zrozumienia, że poza losem pasierba cały czas obawia się ona o los własnych dzieci i że w związku z tym oczekuje wysiłków nadzwyczajnych („plus quordinaires”)

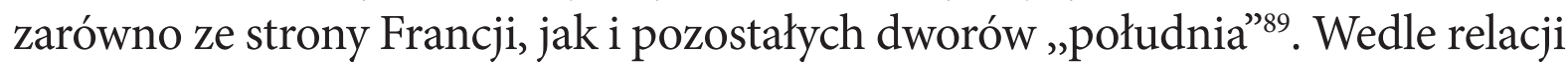
Dumonta Radziwiłłowa miała wiele sobie obiecywać po francuskich zapewnieniach, które ułatwiłyby jej drogę wyjścia z trudnej sytuacji, w jakiej znaleźli się oni razem z pasierbem za rzekome przywiązanie do praw Rzeczypospolitej ${ }^{90}$.

Warto podkreślić, że wszelkie próby wpłynięcia na postawę mocarstw na rzecz kontrowersyjnej postaci Karola Stanisława zostały podjęte samodzielnie przez Annę Luizę, która jeszcze w październiku narzekała na brak listów ze strony opiekuna ${ }^{91}$. Z braku pewnego kanału komunikacji oraz z powodu poważnych problemów finansowych pasierb i macocha nie pozostawali w trwałym kontakcie korespondencyjnym, a jedynie nieregularnie komunikowali się za pośrednictwem osób zaufanych ${ }^{92}$. Sam „Panie Kochanku” dopiero w grudniu 1764 r. skontaktował się po raz pierwszy z księżną Radziwiłłową, wyrażając swoją aprobatę dla jej poczynań dyplomatycznych skierowanych w stronę dworów „południa”" ${ }^{33}$. Wtedy też pasierb zalecił ma-

${ }^{87}$ J.F. Dumont do ks. de Praslin, Dantzick, 21 XI 1764, ibidem, k. 229.

${ }^{88}$ „La lettre de M. le Mis de Paulmy et l'espérance que ce Ministre luy fait concevoir d'une protection proportionnée à l'état désespéré des affaires de sa maison, l’ont un peu calmée [...]". Zob. ibidem.

${ }^{89}$ Ibidem, k. 230.

${ }^{90}$ Ibidem.

${ }^{91}$ A.L. Radziwiłłowa do K.S. Radziwiłła, Gdańsk, 12 X 1764, AGAD, AR, IV, 620, s. 107.

${ }^{92}$ M.in. wspomniany kurier Jana Klemensa Branickiego oraz inni kurierzy jadący np. z Konstantynopola do Sztokholmu, zob. J.F. Dumont do ks. de Praslin, Dantzick, 8 IX 1764, AMAE, CP Dantzig 21, k. 169.

${ }^{93}$ Odebranie tego listu znajduje odzwierciedlenie w oryginale odpowiedzi Anny Luizy, zachowanego obecnie w Archiwum Radziwiłłów. Zob. A.L. Radziwiłłowa do K.S. Radziwiłła, Gdańsk, 5 XII 1764, AGAD, AR, IV, 620, s. 108. 
cosze podporządkowanie się nowej władzy Stanisława Augusta, aby uczynić mediację mocarstw bardziej efektywną. W intencji Karola Stanisława pogodzenie się Radziwiłłów z nowym królem, tak jak uczynił to hetman Branicki, ułatwi pośredniczącym dworom spełnienie ich obietnic i przywrócenie rodziny w majątkach i na urzędach ${ }^{94}$. Jeszcze w połowie grudnia $1764 \mathrm{r}$. Anna Luiza miała okazję ponowić swoje apele o francuską pomoc w rozmowach z markizem de Bausset, francuskim dyplomatą zmierzającym przez Gdańsk na placówkę w Petersburgu ${ }^{95}$. W tym samym okresie minister Praslin polecił Dumontowi informować osoby zainteresowane w Gdańsku, w tym księżną Radziwiłłową, o wstępnym rozpoczęciu negocjacji na dworze w Wiedniu i przedstawieniu nowemu królowi warunków uznania ${ }^{96}$.

Zgodnie z sugestiami pasierba w styczniu 1765 r. Anna Luiza wyruszyła z Gdańska do Warszawy, aby pogodzić się z nowym królem ${ }^{97}$. Wyjazd ten poprzedzony był długimi konsultacjami z zausznikami księżnej („les confidens”), którzy w relacjach Dumonta nie są wymienieni z imienia i nazwiska. Mieli oni przekonać Annę Luizę, że dla dobra własnego potomstwa powinna ona pogodzić się z królem i Czartoryskimi, aby zapobiec realizacji złowrogich planów, jakie mogliby oni spróbować przedsięwziąć w stosunku do samej księżnej, jak i jej dzieci. Tym, co miało powstrzymywać Annę Luizę do początku 1765 r., były moralne rozterki lojalnej wobec pasierba macochy, zaniepokojonej trudną sytuacją materialną i polityczną tego ostatniego. Pozostałe wątpliwości miały brać się z obawy o reakcję mocarstw „południa”, które, jak wiemy, ogólnie deklarowały wobec Radziwiłłów swoje poparcie w staraniach o odzyskanie przez Karola Stanisława dóbr oraz urzędów, a które w tej sytuacji mogłyby z dezaprobatą przyjąć pojednanie macochy „Panie Kochanku” ze Stanisławem Augu-

${ }^{94}$ J.F. Dumont do ks. de Praslin, Dantzick, 5 XII 1764, AMAE, CP Dantzig 21, k. 241.

${ }^{95}$ J.F. Dumont do ks. de Praslin, Dantzick, 12 XII 1764, ibidem, k. 252. Mathieu Nicolas de Bausset był dyplomatą mianowanym na następcę Louisa Auguste’a Le Tonneliera barona de Breteuil, poprzedniego ambasadora w Petersburgu z lat 1760-1763. Na swoje miejsce przeznaczenia Bausset dotarł jednak dopiero w maju 1765 r. Zob. Introduction, [w:] Sbornik Imperatorskogo Russkogo Istoriczeskogo Obszczestwa, 140, red. K.A. Gubastov, Sankt Petersburg 1912, s. XXXIII. O roli Gdańska jako miejsca przejazdu wielu osobistości, a więc i kanału informacji zob. E. Cieślak, Francuska placówka, s. 24-25.

${ }^{96}$ Jednocześnie Anna Luiza dawała Dumontowi do zrozumienia, że wciąż oczekuje na „jakąś pocieszającą odpowiedź” („quelques avis consolans”) ze strony księcia de Praslin. O oczekiwaniach Radziwiłłowej w przededniu publicznego ogłoszenia tych zapewnień pisał J.F. Dumont do ks. de Praslin, Dantzick, 12 XII 1764, AMAE, CP Dantzig 21, k. 251-252.

${ }^{97}$ J.F. Dumont do ks. de Praslin, Dantzick, 19 I 1765, AMAE, CP Dantzig 22, k. 28. 
stem ${ }^{98}$. Decydując się jednak pozostawić dzieci dla bezpieczeństwa w Gdańsku, a sprawy pasierba w rękach dyplomatów monarchii Habsburgów i Burbonów, Anna Luiza udała się w styczniu 1765 r. do Warszawy, gdzie została przyjęta na nowym dworze.

Do Gdańska macocha „Panie Kochanku” powróciła dopiero po świętach Wielkanocy 1765 r. W międzyczasie do Dumonta docierały informacje o kolejnych krokach Radziwiłłowej, która miała odrzucić z pełną stanowczością wszystkie "podstępne propozycje” („propositions insidieuses”) Czartoryskich oraz Stanisława Augusta ${ }^{99}$. O tym, co dokładnie działo się podczas pobytu Anny Luizy w Warszawie, wiemy z relacji jej samej, spisanej w kolejnym liście do francuskiego ministra spraw zagranicznych. Aby położyć kres wszelkim podejrzeniom, jakie mogłyby zrodzić się przy okazji pobytu na wrogim dla pasierba dworze Stanisława Augusta, Radziwiłłowa z wyprzedzeniem tłumaczyła swoje intencje oraz relacjonowała przebieg samej wizyty w liście do księcia de Praslin z 13 kwietnia 1765 r.: „Je reviens de Varsovie, ou je me suis rendu sur les invitations reiterés du Prince Czartoryski grand chancellier de Lithuanie. Il ne m’a pas été difficil de démontrer à ce Ministre les injustices criantes que l'on exerce contre mon beau fils. J'en ai parlé au nouveau Roy avec cette franchise, et liberté que la bonne cause inspire; touts les adoucissements qu'on m’a présenté n’ont été que des propositions d'arangements qui me rendroient complice d'une oppression aussi injuste, l'honneur et la conscience ne mont pas permis d'accepter les avantages personels que l'on me faisoit entrevoir. [...]"100. Ponownie odwołując się do pośrednictwa Francji w imieniu Karola Stanisława, Anna Luiza w sposób bardzo plastyczny opisywała aktualną sytuację we włościach radziwiłłowskich, gdzie wszystkie majątki rodziny miały być rabowane oraz bezczeszczone („pillés, ravagés”) w toku popełnianych tam przez konfederację litewską przestępstw ${ }^{101}$. Ponadto bezcenne kolekcje oraz przedmioty luksu-

${ }^{98}$ Ibidem.

${ }^{99}$ J.F. Dumont do ks. de Praslin, Dantzick, 16 III 1765, ibidem, k. 81.

${ }^{100}$ A.L. Radziwiłłowa do ks. de Praslin, Dantzick, 13 IV 1765, ibidem, k. 103. W relacji tej zwraca uwagę fakt, że Anna Luiza w zasadzie nie określała dokładnie, jakie propozycje składano jej na dworze nowego króla. Francuskie ministerstwo było jednak na bieżąco informowane o wydarzeniach w Warszawie dzięki relacjom Wojciecha Jakubowskiego. Na temat pobytu Radziwiłłowej w stolicy w lutym 1765 r. zob. W. Jakubowski do ks. de Praslin, Varsovie, 2 II i 23 II 1765, AMAE, CP Pologne 288, k. 168, 177.

${ }^{101}$ A.L. Radziwiłłowa do ks. de Praslin, Dantzick, 13 IV 1765, AMAE, CP Dantzig 22, k. 103. 
sowe miały być rozprzedawane, a ziemia pozostawać ugorem, co zmuszało poddanych Karola Stanisława do żebrania w sąsiednich dobrach („forcés d'aller mandier à d'autres habitations"). Wszystko to miało być oczywiście karą za okazaną przez „Panie Kochanku” patriotyczną gorliwość podczas bezkrólewia 1764 r. oraz lojalność demonstrowaną wobec zaprzyjaźnionych dworów, które poprzez swoje deklaracje gwarantowały przecież obronę polskich wolności ${ }^{102}$.

Nieco inne światło na warszawski pobyt księżnej rzuca jej list do pasierba z 3 marca 1764 r. ${ }^{103}$ Będąc w stolicy, starała się ona nawiązać kontakt $\mathrm{z}$ dawnym stronnikiem saskim Jerzym Augustem Mniszchem, marszałkiem nadwornym koronnym ${ }^{104}$. Szczegóły pertraktacji z Czartoryskimi pomijała, twierdząc, że „dwaj oddawcy listów moich na moją całą robotę patrzyli i dyskursów słuchali" ${ }^{105}$. Podkreślała natomiast użyteczność samej wizyty w stolicy dla pokrzepienia „skrytych przyjaciół”: „Ja to tylko z podziwieniem całej Warszawy byłam odważna i wszystkim mówiłam bez ogródki prawdę i wielom oczy otworzyła, że teraz więcej widzą niżeli pierwej, daj Boże, żebyśmy tylko mocne plecy mieli, to z honorem wynidziem na swoje"106. Na zakończenie zachęcała Karola Stanisława do bliższej współpracy w celu ratowania rodowych majętności. Później Anna Luiza wspominała lojalność, którą zademonstrowała, wyrażając pretensje pod adresem pasierba za zaniedbywanie obowiązku korespondowania ${ }^{107}$.

${ }^{102}$ Tego samego dnia prawie identyczny w treści list Anna Luiza zaadresowała również do królewicza Ksawerego, pełniącego obowiązki regenta Saksonii, zob. SHSA, Geheimes Kabinett 10026, 3583/5 (poszyt bez paginacji). W odpowiedzi z 19 maja 1765 r. Ksawery zapewniał Annę Luizę o swoim stałym poparciu dla sprawy Radziwiłłów na dworach państw zaprzyjaźnionych. Zob. brulion odpowiedzi księcia w tym samym poszycie.

${ }^{103}$ A.L. Radziwiłłowa do K.S. Radziwiłła, Praga Warszawska, 3 III 1765, AGAD, AR, IV, 620, s. $109-110$.

${ }^{104}$ Postawa marszałka była jednak w czasie ostatniej elekcji bierna. M. Czaplińska, Mniszech Jerzy August (1715-1778), [w:] E. Rostworowski (red.), PSB, 21, Wrocław-Warszawa i in. 1976, s. 472.

${ }^{105}$ A.L. Radziwiłłowa do K.S. Radziwiłła, Praga Warszawska, 3 III 1765, AGAD, AR, IV, 620, s. 109.

${ }^{106}$ Ibidem, s. 110.

107 „A że dotychczas żadnej nawet litery od niego nie mam, wnoszę stąd odmianę afektu Jego ku mnie, na którą wiem, żem nie zasłużyła, owszem spodziewałam się za moje przywiązanie (które cały świat widział) wdzięczności i większego przywiązania W.X. Mości ku mnie”. Zob. A.L. Radziwiłłowa do K.S. Radziwiłła, Fuxbad k. Pragi, 19 V 1766, AGAD, ibidem, s. 155. 
$\mathrm{Z}$ odpowiedziami na oba listy księżnej do dworu wersalskiego minister Praslin zwlekał odpowiednio długo, bo aż do lipca 1765 r., czyli do momentu, gdy negocjacje wiedeńskie w sprawie uznania majestatu Stanisława Augusta powoli zbliżały się do końca ${ }^{108}$. Jeszcze w maju 1765 r. Karol Stanisław miał prosić macochę o cierpliwe wyczekiwanie rezolucji mocarstw, z których miały wyniknąć pozytywne skutki („les heureux effets”) dla sprawy Radziwiłłów $^{109}$. Natomiast pogarszająca się sytuacja materialna i osobista Anny Luizy budziła szczere, wydaje się, zaniepokojenie konsula Dumonta, który jeszcze w czerwcu 1765 r. odnosił się do problemu, jakim był brak namacalnych korzyści wypływających z obietnic mocarstw dla sprawy polskich „patriotów" 110 . Natomiast późna odpowiedź księcia de Praslin dla Anny Luizy z 12 lipca 1765 r. została poprzedzona listem ministra do Dumonta, zawierającym odpowiednie didaskalia. W swojej odpowiedzi dla Radziwiłłowej francuski minister powtarzał puste zapewnienia o niezmiennej życzliwości i trwałym poparciu Ludwika XV dla sprawy Radziwiłłów, dodając jednak przy samym końcu, że Wersal zastosuje obiecane „bons offices” dopiero, gdy okoliczności będą ku temu bardziej sprzyjające („lorsque les circonstances seront convenables") ${ }^{111}$. Takie odłożenie sprawy na czas nieokreślony było ewidentną zapowiedzią rezygnacji Francji z dalszego popierania kłopotliwej sprawy „Panie Kochanku”. Potwierdzeniem był równoczesny list księcia de Praslin do Dumonta, w którym minister informował swojego podwładnego, że uznanie Stanisława Augusta jest już nieodległe i że mocarstwa zrobiły, co mogły w sprawie Radziwiłła, dodając, że nikt nie powinien był liczyć na zupełne przywrócenie księcia na jego dobrach i urzędach, a jedynie na złagodzenie represji ${ }^{112}$. Jednocześnie Praslin absolutnie zakazywał Dumontowi

${ }^{108}$ Z. Zielińska, Polska w okowach, s. 421.

${ }^{109}$ J.F. Dumont do ks. de Praslin, Dantzick, 18 V 1765, AMAE, CP Dantzig 22, k. 143.

${ }^{110} \mathrm{~W}$ tym czasie, wedle relacji Dumonta, Anna Luiza z obawy przed odebraniem jej syna Hieronima Wincentego miała rozważać wyjazd do Wiednia. Plan ten nie mógł jednak zostać zrealizowany ze względu na bardzo złą sytuację materialną i długi zaciągnięte przez księżną podczas pobytu w Gdańsku. Zob. J.F. Dumont do ks. de Praslin, Dantzick, 22 VI 1765, ibidem, k. $183-184$.

${ }^{111}$ Ks. de Praslin do A.L. Radziwiłłowej, Compiègne, brulion listu z 12 VII 1765, ibidem, k. 200.

${ }^{112}$ Złagodzenie represji wynegocjowane podczas pertraktacji o uznanie elekcji Stanisława Augusta na dworze Marii Teresy zostało przez Karola Stanisława odrzucone. Według postanowień wiedeńskich Radziwiłł miał powrócić do swoich ziem w Koronie, podczas gdy dobra litewskie miały pozostać w sekwestrze do czasu spłacenia wszystkich długów. Miał on także 
informowania księżnej o zaawansowanym stanie negocjacji wokół uznania Stanisława Augusta ${ }^{113}$. W kolejnym liście z 18 sierpnia 1765 r. Praslin zalecał kontynuowanie przez Dumonta słownego popierania „patriotów” poprzez szerokie zapewnienia o dobrej woli Francji, zaznaczając, że przedstawiciele i przedstawicielki polskiej opozycji nie mogą liczyć na pomoc finansową dworu w Wersalu, który nie był przecież powodem ich popadnięcia w niełaskę $^{114}$. O możliwość wspomożenia Anny Luizy Dumont dopytywał wcześniej w związku z bardzo złą sytuacją finansową księżnej ${ }^{115}$.

Przekazując macosze „Panie Kochanku” kolejną odpowiedź od księcia de Praslin, Dumont miał pozostawić ją pełną ufności w dobre intencje Francji oraz w przekonaniu, że najlepiej zrobiłaby, wysyłając dzieci dla bezpieczeństwa do Pragi, dopóki sytuacja Karola Stanisława nie ulegnie polepszeniu. Natomiast sama Radziwiłłowa miała w towarzystwie francuskiego konsula wyrażać chęć dołączenia do pasierba w Preszowie (niem. Eperies) na terenie Królestwa Węgier, aby tam uzgodnić z nim dalszy plan postępowania po rychłym uznaniu Stanisława Augusta przez dwory „południa”"116. Opuszczając w sierpniu 1765 r. Gdańsk, Anna Luiza przestała pojawiać się w relacjach francuskiego konsula, który utracił kontakt z księżną. Kolejnymi miejscami rezydowania hetmanowej były Drezno w październiku 1765 r. ${ }^{117}$, a następnie czeska Praga, gdzie Anna Luiza przebywała od końca października tego samego roku do jesieni roku następnego $^{118}$. Tam też macocha spotkała się z pasierbem, po raz pierwszy od czasu elekcji Stanisława Augusta i emigracji „Panie Kochanku”119. W Pradze

zrzec się tytułu wojewody wileńskiego. O rezultatach negocjacji poinformował księcia na przełomie lipca i sierpnia 1765 r. specjalny wysłannik dworu wiedeńskiego radca Andreas Adolf von Krufft, zob. J. Michalski, Radziwiłł Karol Stanisław, s. 251; Z. Zielińska, Polska w okowach, s. 421.

${ }^{113}$ Ks. de Praslin do J.F. Dumont, Compiègne, brulion listu z 12 VII 1765, AMAE, CP Dantzig 22, k. 198-199.

${ }^{114}$ Ks. de Praslin do J.F. Dumont, Compiègne, brulion listu z 17 VIII 1765, ibidem, k. 230.

${ }^{115}$ J.F. Dumont do ks. de Praslin, Dantzick, 20 VII 1765, ibidem, k. 210-212.

${ }^{116}$ J.F. Dumont do ks. de Praslin, Dantzick, 3 VIII 1765, ibidem, k. 222-224.

117 „Madame la Princesse Radziwil a été ici, et le Prince son beau-fils vouloit y venir aussi. Nous avons décliné la visite et conseillé à ce Prince de rester plutôt dans les Etats d'une Puissance plus capable de le protéger". K. Flemming do gen. de Fontenay, Dresden, brulion listu z 3 XI 1765, SHSA, 10026 Geheimes Kabinett, 2744/5, k. 419.

${ }^{118}$ „Listy Anny Luizy z Mycielskich Radziwiłłowej”, AGAD, AR, IV, 620, s. 115-170.

${ }^{119} \mathrm{O}$ planach wyjazdu z Preszowa do Pragi, aby tam spotkać się z Anną Luizą, sam Karol Stanisław informował hetmana Branickiego. Dzięki bliskim kontaktom z kręgiem białostockim 
oboje przygotowali na piśmie propozycje warunków powrotu Karola Stanisława do kraju, co zostało następnie powierzone agentowi Radziwiłła na dworze cesarskim $^{120}$.

W związku z zakończeniem negocjacji wiedeńskich i rychłym uznaniem nowego króla przez Austrię i Saksonię Karol Stanisław podjął decyzję o podróży do Drezna, licząc na wstawiennictwo dworu saskiego, któremu również nie udało się uzyskać za pośrednictwem mocarstw bardzo pożądanych przez siebie apanaży dla królewiczów Ksawerego i Karola. Kwestia ta została odłożona ad acta do najbliższego sejmu, na którym synowie Augusta III mieli próbować samodzielnie przedstawić swoje postulaty. Wedle oczekiwań pasierba i macochy, wtedy też mogłaby powrócić kwestia lojalnej wobec Saksonii familii Radziwiłłów. Przybycie Karola Stanisława do Drezna w 1766 r. nie zostało przyjęte z wielkim entuzjazmem przez dwór saski, który już wcześniej odmówił „Panie Kochanku" zgody na przyjazd w 1765 r. ${ }^{121}$, mimo że nie odrzucano tam całkowicie popierania sprawy rodziny, postrzeganej jako jedynej możliwej przeciwwagi dla Czartoryskich na Litwie. Natomiast o ile wcześniejsze przybycie Anny Luizy nie wzbudziło wielkich zastrzeżeń w Dreźnie, o tyle niezapowiedziany przyjazd jej pasierba w lutym 1766 r. wprawił dwór saski w stan prawdziwej konsternacji: „Monsieur le Prince de Radziwill vient de nous tomber sur les bras, sans nous avoir prévenu de son arrivée. Il ne doit s'arrêter que quelques jours. Vous jugés Monsieur de notre empressement à être débarassé de cette

wiedział o tym od razu polski korespondent Wersalu Wojciech Jakubowski, zob. tenże do ks. de Praslin, Brańsk, 12 X 1765, AMAE, CP Pologne 288, k. 281.

${ }^{120}$ Zob. „Instruction pour le major Sitterman à Vienne, touchante le rétablissement du prince de Radziwiłł en Pologne”, Prague, 29 X 1765, AST, CS Polonia 1/19 (poszyt bez paginacji). Na kopii instrukcji zachowanej w Turynie wśród papierów sardyńskiego ambasadora na dworze Marii Teresy, hrabiego Lodovico Malabaila di Canale, odnotowano podpisy zarówno Karola Stanisława, jak i Anny Luizy. Zob. ibidem.

${ }^{121}$ Wedle relacji francuskiego ministra pełnomocnego w Dreźnie dwór saski bardzo obawiał się wizyty „Panie Kochanku”: „On craint avec raison la présence d’un hôte qui croit mériter de la reconnoissance et dont les affaires domestiques sont tellement dérangées que lon pourroit difficilement se dispenser de le secourir". Zob. baron de Zuckmanel do ks. de Praslin, Dresden, 19 X 1765, AMAE, CP Saxe 51, k. 415. Francuski minister w swojej odpowiedzi przewidywał, że strach ten bierze się z przekonania, iż po przybyciu Radziwiłła do Drezna może się potem okazać praktycznie niemożliwym dla saskiego dworu, aby zmusić byłego wojewodę do odjazdu: „Elle [la Saxe - J.B.] n’auroit peut-être pas été la maîtresse de s’en débarasser quand elle l'auroit voulu [...]". Ks. de Praslin do barona de Zuckmantel, Fontainebleau, brulion listu z 16 XI 1765, ibidem, k. 441. 
visite"122. Takie nastawienie nie mogło dziwić, biorąc pod uwagę postawę księcia, którego zachowanie było uważnie obserwowane i szeroko komentowane przez dyplomatów państw obcych przy dworze saskim: „Prince Radziwil is still here, nor is the time of his departure yet fixed, though I believe this Court is already heartily tired of him. He is a perfect Sarmatian, very barbarous in his manners and address [...]"123.

Aby zapobiec kontynuowaniu dalszych peregrynacji przez Karola Stanisława w stronę Francji, Praslin przekazywał saskiemu dyplomacie przy dworze w Wersalu, aby „Panie Kochanku” zaoszczędził sobie trudów i kosztów ewentualnej podróży z Drezna do Wersalu, a więc dawał jasno do zrozumienia, iż polski magnat nie będzie na dworze Ludwika XV mile widziany ${ }^{124}$. Zamiar Radziwiłła musiał być stanowczy, skoro w liście do pasierba Anna Luiza namawiała go do odłożenia o kilka dni wyjazdu do Mannheimu, co pozwoliłoby jej dotrzeć z Pragi do Drezna na spotkanie ${ }^{125}$.

Ostatecznie kwestie dotyczące Branickiego i Radziwiłła nie zostały zaaranżowane przez państwa „południa” zgodnie z oczekiwaniami polskiej opozycji. Hetman Branicki, pogodzony z królem za pośrednictwem monarszej siostry, a własnej żony Izabeli, zdołał co prawda powrócić do swoich majątków dość szybko po wyniesieniu Stanisława Augusta, ale nie doprowadzono do skasowania reform sejmu konwokacyjnego i likwidacji systemu Komisji Wojskowej, która, jako organ kolegialny, ograniczała jego dotychczasowe uprawnienia. Za porażkę w mediacjach ten najważniejszy stronnik Wersalu został jednak odpowiednio „odszkodowany” przez państwa „sys-

${ }^{122}$ K. Flemming do gen. de Fontenay, Dresden, brulion listu z 16 II 1766, SHSA, 10026 Geheimes Kabinett, 2745/1, k. 57.

${ }^{123}$ P. Stanhope do ks. Grafton, Dresden, 19 II 1766, TNA, SP Poland and Saxony 88/93 (tom nie posiada paginacji).

124 „On n'est pas moins empêché ici de la visite du Pce Radziwill dont on est menacé. Le Ministre m’a assuré qu'il seroit sagement de sépargner les frais de ce voyage, dont il ne retireroit aucune utilité". Gen. de Fontenay do K. Flemminga, Paris, 5 III 1766, SHSA, 10026 Geheimes Kabinett, 2745/1, k. 96.

${ }^{125}$ A.L. Radziwiłłowa do K.S. Radziwiłła, Praga, 23 VI 1766 i 11 VII 1766, AGAD, AR, IV, 620, s. 157-158. Książę Radziwiłł wyrażał wielką chęć udania się do Francji również w obecności francuskiego ministra pełnomocnego w Dreźnie, zob. baron de Zuckmantel do ks. de Praslin, Dresde, 8 II 1766, AMAE, CP Saxe 52, k. 49-50. W odpowiedzi francuski minister rekomendował swojemu podwładnemu powstrzymywanie Radziwiłła od podjęcia takiego kroku: „Il est certain qu'il ne feroit que nous importuner par ses sollicitations [...]”. Zob. ks. de Praslin do barona de Zuckmantel, Versailles, brulion odpowiedzi z 3 III 1766, ibidem, k. 60. 
temu południowego" hiszpańskim Orderem Złotego Runa w rok po zakończonych negocjacjach w Wiedniu ${ }^{126}$. Inna natomiast była sytuacja Karola Stanisława, który najbardziej uporczywie trwał w opozycji wobec nowego króla, odmawiając podporządkowania się władzy Stanisława Augusta i konfederacji Czartoryskich. Odium przestępcy, a zarazem postaci poprzez swoje zachowanie kontrowersyjnej stawiał sprawę Radziwiłła w znacznie gorszym świetle. Francja, wyraźnie dystansując się od groteskowej postaci wojewody wileńskiego, nie przyczyniła się ostatecznie do przywrócenia księcia na jego dobrach i urzędach. Podobnie jak interesy zawiedzionych mediacją mocarstw Wettynów, pretensje Karola Stanisława Radziwiłła legną niedługo potem u podstaw zwrotu antystanisławowskiej opozycji w Rzeczypospolitej ku Katarzynie II, która, rozczarowana dotychczasowym postępowaniem Stanisława Augusta, posłuży się ludźmi dawnej formacji sasko-republikańskiej przeciw królowi, do którego elekcji doprowadziła, a którego detronizację będzie im obiecywać ${ }^{127}$.

Epilog aktywności księżnej Radziwiłłowej przypada na lata 1767-1771. Po krótkim pobycie w Polsce na przełomie 1766 i 1767 r., podczas którego znalazła się m.in. na dworze Jana Klemensa Branickiego w Białymstoku ${ }^{128}$, w marcu 1767 r. Anna Luiza ponownie pojawiła się w Dreźnie. Tam rezydowała przez cztery lata, aż do swojej śmierci ${ }^{129}$, mimo że Karol Stanisław powrócił do ojczyzny w maju tego samego roku, aby objąć funkcję marszałka konfederacji radomskiej. Podczas gdy we wcześniejszym okresie Anna Luiza zajmowała stanowisko pośrednie pomiędzy nieugiętą postawą pasierba a kuszącymi propozycjami Czartoryskich, pozostając ostatecznie przy tym

${ }^{126}$ Wręczenie odbyło się przy okazji wizyty posła francuskiego w Polsce Louisa Gabriela markiza de Conflans w lipcu 1766 r. Poseł francuski uczestniczył w ceremonii wręczania orderu Branickiemu przez sekretarza hiszpańskiego poselstwa w Wiedniu Las Casasa. Zob. Z. Zielińska, Polska w okowach, s. 432.

${ }^{127}$ Po raz pierwszy rosyjski ambasador w Polsce Mikołaj Repnin zaczął rozważać taką opcję w styczniu 1766 r. po awanturze wokół polskiego poselstwa do Francji i swoim rozczarowaniem nowym królem. Zob. ibidem, s. 440. Już w październiku tego samego roku rosyjski minister spraw zagranicznych Nikita Panin upoważnił Repnina do posłużenia się Radziwiłłem w celu uformowania nowego stronnictwa przeciw królowi i Czartoryskim w wypadku niespełnienia rosyjskich żądań odnośnie do dysydentów na sejmie 1766 roku. Zob. ibidem, s. 558.

${ }^{128}$ A.L. Radziwiłłowa do K.S. Radziwiłła, Białystok, 12 I 1767 i 23 I 1767, AGAD, AR, IV, nr 620, s. 171-174.

${ }^{129}$ W. Konopczyński, Konfederacja barska, I, Warszawa 1991, s. 102. 
pierwszym, u schyłku życia przejęła ona rolę zagorzałej przeciwniczki ugody $\mathrm{z}$ dawnymi wrogami rodu ${ }^{130}$.

Podsumowując, rola polityczna Anny Luizy Radziwiłłowej w latach 1764-1765 była ściśle związana ze skomplikowaną sytuacją jej opiekuna, a zarazem pasierba Karola Stanisława „Panie Kochanku”. W odpowiedzi na trudną sytuację rodzinną, w intencji odzyskania majątków i funkcji dla przybranego syna oraz ochrony własnych dzieci, Anna Luiza samodzielnie podjęła zabiegi dyplomatyczne o wstawiennictwo u obcych dworów, które deklarowały wcześniej obronę polskich wolności. Mimo niewielkich rezultatów działania lojalnej wobec pasierba macochy wyróżniały się samodzielną inicjatywą na tle podobnych zabiegów czynionych przez krewne pozostałych nieprzyjaciół nowego króla ${ }^{131}$. Należy podkreślić, że postawa Radziwiłłowej nie była bezinteresowna, gdyż jej zabiegi o zachowanie potęgi rodu miały na celu przede wszystkim zapewnienie przyszłości dzieci, zwłaszcza tych pochodzących z drugiego małżeństwa. Materiał z przeanalizowanej francuskiej korespondencji dyplomatycznej potwierdza obraz dobrej macochy, nakreślony po śmierci Anny Luizy przez proboszcza nieświeskiego Józefa Katenbringa. Wystąpienie księdza było jednak bardzo stonowane: główny nacisk położył on na przywiązanie macochy do pasierba i do rodu niż na troskę o przyszłość dzieci, która prawdopodobnie była ważnym motywem aktywności Anny Luizy. Taki sposób prezentowania macochy był zapewne zgodny z oczekiwaniami samego Karola Stanisława „Panie Kochanku”, który dążył do przywrócenia dawnej świetności rodu.

${ }^{130}$ „Słyszałam mój Książę, że opiekuni, y kuratorowie, przeszli, szukając z W. Ks. Mością ugody. Zmiłuj się mój kochany Książę, nie wchodź w tę ugodę, bo to zapewne na zdradę y wielką szkodę W. Ks. Mości całego domu, a osobliwie Hieronima. Masz W. Ks. Mość dobrą ekskuzę, nie wchodzić w tę ugodę, ponieważ te szkody wszystkie nie jeden W. Ks. Mość masz, ale również i Hieronimek szkoduje, a fortuna nie jest podzielona, więc szkody nie można pomiarkować”. A.L. Radziwiłłowa do K.S. Radziwiłła, Drezno, 13 XII 1768, AGAD, AR, IV, 621, s. $44-45$.

${ }^{131}$ Wspomniana Anna Paulina z Sapiehów Jabłonowska, również przebywająca w tym samym czasie w Gdańsku, odgrywała rolę podobną w stosunku do wuja Jana Klemensa Branickiego, co Anna Luiza w stosunku do pasierba Karola Stanisława. Jednak zabiegi tej pierwszej były cały czas inspirowane przez samego hetmana, który przekazywał siostrzenicy instrukcje zawierające wskazówki działania oraz listy do konsula Dumonta. Jej aktywność nie była więc równie samodzielna jak ta, którą przejawiała macocha „Panie Kochanku”. Niemniej jednak, w relacjach francuskiego dyplomaty Anna Paulina pojawia się równie często, co Anna Luiza. Na temat tej postaci zob. m.in. J.F. Dumont do ks. de Praslin, Dantzick, 3 VII 1765, AMAE, CP Dantzig 22, k. 193-197. 


\section{Jakub Bajer, Andrea Mariani \\ A PERFECT STEPMOTHER: ACTIVITIES OF ANNA LUIZA RADZIWIŁŁOWA NÉE MYCIELSKA IN THE LIGHT OF FRENCH DIPLOMATIC CORRESPONDENCE (1764-1765)}

\section{Summary}

Anna Luiza Radziwiłłowa née Mycielska belonged to the aristocracy of the Grand Duchy of Lithuania. After a first marriage with a minor member of the Radziwiłł family, she remarried to the grand hetman Michał Kazimierz "Rybeńko" who was not only the chief of the family, but also one of the most influential politicians in the Polish-Lithuanian Commonwealth. After the death of "Rybeńko" (1762) and king August III (1763) Radziwiłł's son from the first marriage, Karol Stanisław "Panie Kochanku” became the head of family's political clientele and faced the problem of the election of a new king. Being a major member of the republican faction opposing the Czartoryski family and its candidate to the Polish throne, Stanisław Poniatowski, "Panie Kochanku" had to leave the country, while his possessions where sequestered by his political opponents. Given the political climate, Anna Luiza moved to the city of Gdańsk which — although belonging to the Commonwealth - enjoyed a high level of autonomy. From there she tried to gain French political support for her stepson. At the same time she rejected the proposal of the Czartoryski family to pay allegiance to the new king in return for her possessions. From August 1764 to August 1765, Anna Luiza spent most of time in Gdańsk, looking for the best possible way out for herself and her stepson, so that they could return to their estates in the Polish-Lithuanian Commonwealth. Using diplomatic channels, Anna Luiza tried to convince the French consul in Gdańsk, Dumont, that France and its allies (Austria, Spain and Saxony) should help her and her stepson win back their political position. She even wrote letters to the most important people at the court of Versailles and presented herself as being persecuted for opposing to the new king. On most occasions, Anna Luiza described herself as anxious for her own children, who allegedly were to be taken away from her by the new king and the Czartoryski family in retaliation for the previous political activity of Karol Stanisław. In response to these petitions, France and her allies promised Anna Luiza and other Polish republicans to discuss their affairs during the negotiations about the international acknowledgment of the new king of Poland. Still, after one year, the only thing that Versailles managed to arrange was the withdrawal of some charges against Karol Stanisław "Panie Kochanku”. However, the French foreign minister kept up the appearance, telling Anna Luiza and other republicans that Versailles was not going to forsake its claims against Stanisław August. Abandoned by France, Anna Luiza and Karol Stanisław went to Saxony to beg the friendly court of Dresden for help in ar- 
ranging their situation during the next diet in Poland. From this moment onwards, she disappeared from the French correspondence from Gdańsk.

\section{Bibliografia}

Źródła drukowane

Catalogus provinciae Masoviae Societatis Jesu ex Anno 1764 ad Annum 1765, Varsavia [1764].

Katenbring J., Opisanie dzienne pogrzebów JO X Anny z Micielskich Radziwiłłowy wojewodziny wileńskiej hetmanowy W. WXL y JO X Jmci Hieronima Radziwiłła podkomorzego W. WXL starosty sądowego województwa mińskiego rotmistrza kawaleryi narodowey kawalera orderów polskich św. Huberta obchodzonego w Nieświzu 1787 czerwca 20 dnia, Wilno 1787.

Kurier Polski 10, 1758.

Matuszewicz M., Pamiętniki Marcina Matuszewicza kasztelana brzeskiego-litewskiego 1714-1765, 4 tomy, red. A. Pawiński, Warszawa 1876.

Radziwiłł K.S., Korespondencya księcia Karola Stanisława Radziwiłła wojewody wileńskiego „Panie Kochanku” (1744-1790) z archiwum w Werkach, red. C. Jankowski, Warszawa 1898.

Radziwiłł K.S., Korespondencya ks. Karola Stanisława Radziwiłła wojewody wileńskiego „Panie Kochanku” (1762-1790) ze zbiorów familijnych, red. K. Waliszewski, Kraków 1888.

Radziwiłł K.S., Listy księcia Karola Stanisława Radziwiłła „Panie Kochanku” (1751-1790) z różnych archiwów, red. E. Łuniński, Warszawa 1906.

Sbornik Imperatorskogo Russkogo Istoriczeskogo Obszczestwa, 140, ed. K.A. Gubastov, Sankt Petersburg 1912.

\section{Opracowania}

Aleksandrowska E., Mycielski Stanisław (1743-1818), [w:] E. Rostworowski (red.), Polski Słownik Biograficzny, 22, Wrocław-Warszawa i in. 1977, s. 346-347.

Bernatowicz T., „Akt bardzo rzadko praktykowany”. Uroczystość obłóczyn księżnej Teofili z Leszczyńskich Wiśnowieckej we Lwowie, [w:] T. Bernatowicz (red.), Polska i Europa w dobie nowożytnej. Księga pamiątkowa dedykowana profesorowi Juliuszowi A. Chrościckiemu, Warszawa 2009, s. 325-332.

Cieślak E., Francuska placówka konsularna w Gdańsku w XVIII wieku. Status prawny - zadania - działalność, Kraków 1999.

Czamańska I., Wiśniowieccy. Monografia rodu, Poznań 2007.

Czaplińska M., Mniszech Jerzy August (1715-1778), [w:] E. Rostworowski (red.), Polski Słownik Biograficzny, 21, Wrocław-Warszawa i in. 1976, s. 470-474. 
Dymnicka-Wołoszyńska H., Radziwiłł Michał Kazimierz zw. Rybeńko (1702-1762), [w:] E. Rostworowski (red.), Polski Słownik Biograficzny, 30, Wrocław-Warszawa i in. 1987, s. 299-306.

Dymnicka-Wołoszyńska H., Radziwiłłowa z Mycielskich Anna Ludwika (1729-1771), [w:] E. Rostworowski (red.), Polski Słownik Biograficzny, 30, WrocławWarszawa i in. 1987, s. 387-388.

Dygdała J., Z życia towarzyskiego polskich elit szlachecko-magnackich w Gdańsku w połowie 1757 roku (Przebendowscy, Adam Kazimierz Czartoryski i wielu innych), [w:] T. Kostkiewiczowa (red.), Przyjemności w kulturze epoki rozumu, Warszawa 2011, s. 207-219.

Judkowiak B., Franciszka Urszula Radziwiłłowa - w poszukiwaniu własnego głosu. Propozycje interpretacyjne, dokumentacyjne i edytorskie, Poznań 2013.

Karkucińska W., Anna Katarzyna z Sanguszków Radziwiłłowa (1676-1746): działalność gospodarcza i mecenat, Warszawa 2000.

Konopczyński W., Konfederacja barska, I, Warszawa 1991.

Michalski J., Radziwiłł Karol Stanisław zw. Panie Kochanku (1734-1790), [w:]

E. Rostworowski (red.), Polski Słownik Biograficzny, 30, Wrocław-Warszawa i in. 1987, s. 248-262.

Sajkowski A., Staropolska miłość. Z dawnych listów i pamiętników, Poznań 1981. Sajkowski A., Z dziejów teatru nieświeskiego (1746-1762), Pamiętnik Teatralny 10, 3, 1961, s. 399-433.

Szczygielski W., Mycielski Józef (1733-1789), [w:] E. Rostworowski (red.), Polski Słownik Biograficzny, 22, Wrocław-Warszawa i in. 1977, s. 336-337.

Szczygielski W., Mycielski Maciej (1690-1747), [w:] E. Rostworowski (red.), Polski Słownik Biograficzny, 22, Wrocław-Warszawa i in. 1977, s. 341-342.

Zielińska Z., Polska w okowach „systemu północnego” 1763-1766, Kraków 2012. 
